\title{
Assessing the role of dust deposition on phytoplankton ecophysiology and succession in a low-nutrient low-chlorophyll ecosystem: a mesocosm experiment in the Mediterranean Sea
}

\author{
V. Giovagnetti ${ }^{1}$, C. Brunet ${ }^{1}$, F. Conversano ${ }^{1}$, F. Tramontano ${ }^{1}$, I. Obernosterer ${ }^{2,3}$, C. Ridame ${ }^{4}$, and C. Guieu ${ }^{5,6}$ \\ ${ }^{1}$ Stazione Zoologica Anton Dohrn, Villa Comunale, 80121, Naples, Italy \\ ${ }^{2}$ Université Pierre et Marie Curie-Paris 6, UMR7621, LOMIC, Observatoire Océanologique, 66650 Banyuls/Mer, France \\ ${ }^{3}$ CNRS, UMR7621, LOMIC, Observatoire Océanologique, 66650 Banyuls/Mer, France \\ ${ }^{4}$ Laboratoire d'Océanographie et du Climat: Expérimentations et Approches Numériques (LOCEAN), CNRS-Université \\ Paris VI, Campus Jussieu, Paris, France \\ ${ }^{5}$ Laboratoire d'Océanographie de Villefranche/Mer, CNRS-INSU, UMR7093, Observatoire Océanologique, 06230, \\ Villefranche/Mer, France \\ ${ }^{6}$ Université Pierre et Marie Curie-Paris 6, UMR7093, LOV, Observatoire Océanologique, 06230, Villefranche/Mer, France \\ Correspondence to: C. Brunet (christophe.brunet@szn.it)
}

Received: 30 November 2012 - Published in Biogeosciences Discuss.: 21 December 2012

Revised: 19 March 2013 - Accepted: 12 April 2013 - Published: 3 May 2013

\begin{abstract}
In this study, we investigate the response of the phytoplankton community, with emphasis on ecophysiology and succession, after two experimental additions of Saharan dust in the surface water layer of a low-nutrient low-chlorophyll ecosystem in the Mediterranean Sea. Three mesocosms were amended with evapocondensed dust to simulate realistic Saharan dust events, while three additional mesocosms were kept unamended and served as controls. The experiment consisted in two consecutive dust additions and samples were daily collected at different depths $(-0.1$, -5 and $-10 \mathrm{~m}$ ) during one week, starting before each addition occurred. Data concerning HPLC pigment analysis on two size classes $(<3$ and $>3 \mu \mathrm{m})$, electron transport rate (ETR) vs. irradiance curves, non-photochemical fluorescence quenching (NPQ) and phytoplankton cell abundance (measured by flow cytometry), are presented and discussed in this paper. Results show that picophytoplankton mainly respond to the first dust addition, while the second addition leads to an increase of both pico- and nano/microphytoplankton. Ecophysiological changes in the phytoplankton community occur, with NPQ and pigment concentration percell increasing after dust additions. While biomass increases after pulses of new nutrients, ETR does not greatly vary between dust-amended and control condi-
\end{abstract}

tions, in relation with ecophysiological changes within the phytoplankton community, such as the increase in NPQ and pigment cellular concentration. A quantitative assessment and parameterisation of the onset of a phytoplankton bloom in a nutrient-limited ecosystem is attempted on the basis of the increase in phytoplankton biomass observed during the experiment.

The results of this study are discussed focusing on the adaptation of picophytoplankton to nutrient limitation in the surface water layer, as well as on size-dependent competition ability in phytoplankton.

\section{Introduction}

Over the past few decades, strong efforts have been devoted to the investigation of the deep chlorophyll maximum (DCM), an oceanographic phenomenon widespread in oligotrophic pelagic ecosystems, with several studies being focused on DCM formation and maintenance, as well as the biological and ecological features of its phytoplankton community (e.g., Cullen, 1982; Gould, 1987; Pérez et al., 2006). Differently, surface layer phytoplankton communities have been less studied (e.g., Marañón, 2005; Davey et al., 2008; Moore 
et al., 2008), because usually characterised by phytoplankton low biomass and productivity, due to small-sized (mainly prokaryotic) cells dominance and, thus, a lower ecological and biogeochemical relevance when compared to DCM or coastal ecosystems. In fact, during oceanographic cruises, the first ten metres of the water column are generally sampled once, causing a poor amount of data describing the biotic and abiotic properties of these water masses. However, being in direct contact with the atmosphere, pelagic surface waters can be subjected to rapid and severe changes in temperature, light and nutrient concentrations, especially when a climatechanging scenario is considered (Marinov et al., 2010).

Given the high amount of biogeochemically-relevant elements contained in the continental crust (Wedepohl, 1995), the atmosphere is vehicle of a significant (or even dominant) transport of natural and anthropogenic nutrients, and trace metals, from continents to ocean surface (Duce et al., 1991; Guerzoni et al., 1999; Paerl et al., 1999). By affecting nutrient concentration and supply in surface waters, atmospheric dust deposition can impact phytoplankton physiology (e.g., photosystem [PS] II functioning, and adjustments in PSII:PSI stoichiometry; Strzepek and Harrison, 2004; Behrenfeld et al., 2009) and ecology (e.g., cell size and community structure; Eppley and Peterson, 1979; Finkel et al., 2010), as well as ocean productivity and carbon sequestration (e.g., Jickells et al., 2005; Mahowald et al., 2005). Specific physiological responses have been reported in phytoplankton communities of the tropical Pacific on the basis of PSII fluorescence (dark-adapted photochemical efficiency), in relation to a different regulation of the electron transport chain (photosynthesis and respiration) and pigment-protein composition, corresponding to different conditions of iron and nitrogen availability (Behrenfeld et al., 2006).

Although dust deposition increases the input of micro- and macronutrients and usually enhances phytoplankton growth, excess addition of trace metals (e.g., copper; $\mathrm{Cu}$ ) and pollutants has been recently reported to negatively impact marine ecosystem functioning. For instance, toxicity of $\mathrm{Cu}$ associated with atmospheric pulses has been demonstrated by bioassay experiments (Paytan et al., 2009), and by combining direct aerosol measurements and satellite observations in the western Mediterranean Sea (Jordi et al., 2012). Increasing cellular concentrations of $\mathrm{Cu}$ inhibit algal photosynthesis and growth, by altering the electron transport and the number of functional PSII reaction centers (Jordi et al., 2012 and references therein).

The effect of atmospheric inputs (especially of iron) on ocean regions where nutrient concentration is high, yet chlorophyll is low (high-nutrient low-chlorophyll, HNLC), has received great attention (e.g., Boyd et al., 2007; Blain et al., 2008). However, several studies, based on microcosm experiments, have been performed to better understand the influence of atmospheric dust deposition on the functioning and productivity in low-nutrient low-chlorophyll (LNLC) environments, either in the Atlantic Ocean (Blain et al., 2004;
Mills et al., 2004; Moore et al., 2008; Marañón et al., 2010), Pacific Ocean (Law et al., 2011), or Mediterranean Sea (e.g., Pulido-Villena et al., 2008; Wagener et al., 2010).

The Mediterranean Sea might receive high rates of aeolian dust, of both natural (Saharan) and anthropogenic origin, over wide areas (e.g., Guerzoni et al., 1999; Ridame and Guieu, 2002; Pulido-Villena et al., 2008). These atmospheric inputs probably represent the dominant source of external nutrients reaching offshore surface mixed layers (Bartoli et al., 2005; Guieu et al., 2010a). In western Mediterranean oligotrophic areas, significant amounts of iron (Bonnet and Guieu, 2006) and phosphorus (Ridame and Guieu, 2002) can be delivered to the surface waters through Saharan dust pulses (Bergametti et al., 1992; Guieu et al., 2002), and significant changes in the autotrophic (and heterotrophic) community structure have been described in relation to Saharan dust additions (Bonnet et al., 2005; Pulido-Villena et al., 2008; Romero et al., 2011).

In oligotrophic waters, the greatest part of the algal community is formed by tiny cells belonging to the size-class of picophytoplankton $(<3 \mu \mathrm{m}$; Worden and Not, 2008; Finkel et al., 2010), which are characterised by specific ecological and biological traits, such as low sinking rate and package effect, as well as high diversity in photosynthetic pigments and capacity of light utilisation (Raven, 1998; Raven et al., 2005). Picophytoplankton dominance in oligotrophic waters relates to their lower diffusion boundary layer and larger surface area per unit volume, than bigger cells, conferring to small cells a greater efficiency in nutrient and light acquisition and use for cell growth and maintenance (Raven, 1998). Among the picophytoplankton, oxygenic phototrophic marine cyanobacteria belonging to the genera Synechococcus (Waterbury et al., 1979) and Prochlorococcus (Chisholm et al., 1988, 1992) are dominant in oligotrophic waters and often co-occur with changing relative proportions, in relation to their different adaptation to physico-chemical conditions of the water mass (Veldhuis and Kraay, 1990; Partensky et al., 1999). In association with picoeukaryotes, both genera might be considered the major contributors of biomass and primary production in oligotrophic environments (Morel et al., 1993; Partensky et al., 1999). Picophytoplankton relevant contribution to total phytoplankton biomass and production is also well known in the Mediterranean Sea (Magazzù and Decembri, 1995; Casotti et al., 2003; Brunet et al., 2006, 2008).

The interest in studying the diversity and ecology of picophytoplankton has recently grown (Le Gall et al., 2008; Vaulot et al., 2008; Finkel et al., 2010), together with the amount of works on the ecophysiology of picoeukaryotes (Dimier et al., 2007, 2009a, b; Six et al., 2008, 2009; Giovagnetti et al., 2010, 2012). However, despite the high specific diversity and ubiquity of picoeukaryotes was reported (Moon-van der Staay et al., 2001; Díez et al., 2001; Not et al., 2002, 2005), few in field studies performed pigment analysis in fractionated samples, coupled with flow cytometry, to gain 
useful information on picophytoplankton community groups (Brunet et al., 2006, 2008; Not et al., 2005).

In the framework of the DUNE project (a DUst experiment in a low-Nutrient, low-chlorophyll Ecosystem; see Guieu et al., 2010b), a mesocosm experiment (DUNE-2) was conducted to address the following questions: which size class of phytoplankton is the most able to exploit the pulses of new nutrients coming from dust additions, in terms of growth capacity and competition dynamics? Which chemotaxomic group(s) is (are) able to succeed in the competition? And lastly, are pulses of new nutrients affecting the ecophysiological properties of the phytoplankton community, and how?

DUNE-2 was conducted in a coastal LNLC area of Corsica (NW Mediterranean Sea; Guieu et al., 2013), a region subjected to multiple events of dust deposition per year, with observations in recent years of fluxes up to $\sim 22 \mathrm{~g} \mathrm{~m}^{-2}$ (Bonnet and Guieu, 2006; Guieu et al., 2010a, b; Ternon et al., 2010). Here we report data on pigment content (HPLC and ChemTax analysis) of two size classes $(<3$ and $>3 \mu \mathrm{m})$, electron transport rate (ETR) vs. irradiance (I) curves, nonphotochemical fluorescence quenching (NPQ), phytoplankton cell abundance through flow cytometry, together with nutrient analysis.

\section{Materials and methods}

\subsection{Experimental design and sampling strategy}

Two consecutive dust additions onto large clean mesocosms (26 June and 3 July 2010) were performed in the Elbo Bay (Scandola Marine preservation area, $42^{\circ} 37^{\prime} \mathrm{N}, 8^{\circ} 55^{\prime} \mathrm{E}$ ), a coastal area of western Corsica (NW Mediterranean Sea; Guieu et al., 2013). Each dust addition mimicked a high, but still realistic, Saharan dust deposition $\left(10 \mathrm{~g} \mathrm{~m}^{-2}\right.$; Guieu et al., 2010b). The physico-chemical composition of the 'evapocondensed dust', used in this study, reproduced the usual mixing of Saharan dust and anthropogenic polluted air masses occurring in the Mediterranean basin (Guieu et al., 2010b, 2013). Three mesocosms (named DUST Mesocosms: DM1, DM2, and DM3) were amended with $41.5 \mathrm{~g}$ of evapocondensed dust each, while three mesocosms, with no addition of dust, were used as controls (CONTROL Mesocosms: CM1, CM2 and CM3). Moreover, a station, outside the mesocosms was used as control for eventual biases due to the structure of the mesocosms (named "outside"). Samples were daily collected at three depths $(-0.1,-5$ and $-10 \mathrm{~m})$ and at the same hour of the morning, during seven days after each dust addition. Samples at the outside station were taken at the same hour of the morning, but once every two days.

\subsection{Pigment and ChemTax analysis}

Soon after sampling, samples were kept in the dark while carried to the field laboratory, and for each one of them, three litres of seawater were filtered onto polycarbonate fil- ters of $3 \mu \mathrm{m}$ pore size (Merck Millipore, Darmstadt, Germany) and one litre of the filtrate was then poured onto polycarbonate filters of $0.2 \mu \mathrm{m}$. Both filters were rapidly stored in liquid nitrogen. In the laboratory (Stazione Zoologica Anton Dohrn, Naples), frozen filters were mechanically grinded in $100 \%$ methanol and the pigment extract was injected in a Hewlett Packard series 1100 HPLC (HewlettPackard, KennettSquare, PA, USA) with a $\mathrm{C}_{8}$ BDS $3 \mu \mathrm{m}$ Hypersil, IP column (Thermo Fisher Scientific, Waltham, MA, USA). The procedure was the same as described in Dimier et al. (2009a). The mobile phase was composed of two solvent mixtures: methanol and aqueous ammonium acetate (70 : 30), and methanol. Pigments were detected spectrophotometrically at $440 \mathrm{~nm}$ using a Hewlett Packard photodiode array detector model DAD series 1100 . Fluorescent pigments were detected in a Hewlett Packard standard FLD cell series 1100 with excitation and emission wavelengths set at $407 \mathrm{~nm}$ and $665 \mathrm{~nm}$, respectively. Determination and quantification of pigments was performed by using pigment standards from the Danish Hydraulic Institute (DHI) Water and Environment (Hørsholm, Denmark).

The contribution of each phytoplankton group to total phytoplankton biomass (chlorophyll [Chl] $a$ ) was estimated by using the ChemTax programme with input ratios slightly modified from Rodriguez et al. (2006) and Not et al. (2007).

\subsection{Active Chl $a$ fluorescence and photosynthetic efficiency measurements}

Measurements of non-photochemical fluorescence quenching (NPQ) and electron transport rate (ETR) vs. irradiance (I) curves were performed daily on freshly collected samples, with a Phyto-PAM fluorometer (Heinz Walz GmbH, Effeltrich, Germany).

Given phytoplankton low cell abundance in the area of the study, samples were concentrated for PAM measurements. Fifty millilitres of seawater were gently filtered onto polycarbonate filters (Merck Millipore, Darmstadt, Germany) of $0.45 \mu \mathrm{m}$ pore size. Filters were then moistened and cells were immediately resuspended in five millilitres of filtered seawater $(<0.2 \mu \mathrm{m})$. All these operations were done under very low light condition. This procedure was successfully tested in laboratory on coastal mesotrophic samples (Gulf of Naples, Mediterranean Sea) and on diatom cultures with different cell abundances, before applying it to the field experiment, in order to check if the concentration procedure could induce any stress, thus, modifying the results. Since no differences were obtained between concentrated and non-concentrated samples, we applied this method during the mesocosm experiment.

After fifteen minutes in dark, an aliquot of two millilitres was used for measurements of ETR-I curves, and then another two millilitres aliquot to estimate NPQ. 
NPQ was quantified by the Stern-Volmer expression:

$\mathrm{NPQ}=\left(\mathrm{Fm} / \mathrm{Fm}^{\prime}\right)-1$

where $\mathrm{Fm}$ and $\mathrm{Fm}^{\prime}$ are the maximum fluorescence values from dark- and light-exposed samples, respectively. Fm and $\mathrm{Fm}^{\prime}$ were measured after a saturating pulse of red light ( $2400 \mu \mathrm{mol}$ photons $\mathrm{m}^{-2} \mathrm{~s}^{-1}$, lasting $450 \mathrm{~ms}$ ), causing a complete reduction of the photosystem (PS) II acceptor pool.

ETR-I curves were determined applying 10 increasing irradiances (I, from 1 to $1500 \mu \mathrm{mol}$ photons $\mathrm{m}^{-2} \mathrm{~s}^{-1}$ for $2 \mathrm{~min}$ each).

The relative electron transport rate $\left(_{\mathrm{rel}} \mathrm{ETR}_{\max }\right.$, expressed in $\mu \mathrm{mol} \mathrm{e}^{-} \mathrm{m}^{-2} \mathrm{~s}^{-1}$ ) was calculated according to Hofstraat et al. (1994) and Schreiber et al. (1994):

$\mathrm{rel} \mathrm{ETR}_{\max }=\left(\mathrm{Fv}^{\prime} / \mathrm{Fm}^{\prime}\right) \times I \times 0.5$

where, $\mathrm{I}$ is the incident irradiance (expressed in $\mu \mathrm{mol}$ photons $\mathrm{m}^{-2} \mathrm{~s}^{-1}$ ). A factor of 0.5 was applied to correct for the partitioning of photons between PSI and PSII, assuming that excitation energy is evenly distributed between the two photosystems.

ETR-I curves were fitted with the equation of Eilers and Peeters (1988) to estimate the photosynthetic parameters ${ }_{\mathrm{rel}} \alpha^{\mathrm{B}}$, Ek and ${ }_{\text {rel }}$ ETR $_{\max }$.

\subsection{Flow cytometry}

For the enumeration of autotrophic prokaryotic and eukaryotic cells by flow cytometry, subsamples (four millilitres) were fixed with formaldehyde ( $2 \%$ final conc.), and incubated for $30 \mathrm{~min}$ at $4{ }^{\circ} \mathrm{C}$, then quick-frozen in liquid nitrogen and stored at $-80^{\circ} \mathrm{C}$ until analysis. Counts were performed on a FACS-Calibur flow cytometer (Becton Dickinson, San Jose, CA, USA), equipped with a $488 \mathrm{~nm}$ wavelength, $15 \mathrm{~mW}$ Argon laser. Separation of different autotrophic populations was based on their scattering and fluorescence signals according to Marie et al. (2000). Synechococcus spp. was discriminated by its strong orange fluorescence $(585 \pm 21 \mathrm{~nm})$, and pico- and nanoeukaryotes were discriminated by their scatter signals of red fluorescence ( $>670 \mathrm{~nm}$ ). The coefficient of variation was generally $<5 \%$ (Agogué et al., 2004).

\subsection{Statistical analysis}

Data of mesocosm triplicates are presented as mean, after Student's t-test was used to verify that no significant difference occurred between replicates, either in dust-amended or control mesocosms $(p>0.05,31<n<44)$. Student's ttest and multiple regressions conducted on the entire dataset between the measured Chl $a$ concentration in the two size classes and the $\mathrm{Chl} a$ concentration of the specific groups (ChemTax analysis), as well as between cellular abundances (flow cytometry) and $\mathrm{Chl} a$-group specific abundance values (ChemTax analysis), were performed by using the programme Statistica (StatSoft, OK, USA).
The integration of the datasets concerning pigments $(>3 \mu \mathrm{m})$ and nanophytoplankton cellular abundance (flow cytometry) was performed based on the assumption of a very low microphytoplanktonic biomass (so their negligible contribution to total $\mathrm{Chl} a$ ) in relation with the severe oligotrophic field conditions, and in agreement with the very low biomass of large-sized Bacillariophyceae (ChemTax analysis; see result section).

\section{Results}

\subsection{Evolution of the environmental conditions during the experiment}

During the entire experiment, light was high, reaching peaks of $\sim 900 \mu \mathrm{mol}$ photons $\mathrm{m}^{-2} \mathrm{~s}^{-1}$ at the subsurface (Table 1; Guieu et al., 2013). Seawater temperature increased at the surface toward the end of both dust addition periods, indicating changes in stratification over the course of the whole experiment. During the first dust addition period, the temperature data reflect a transition from spring to summer conditions (Table 1; Guieu et al., 2013).

Before the first dust addition was performed, nutrient concentrations were undetectable (nitrate and nitrite) or low (phosphate; Table 1). Nitrate (Ridame et al., 2013) and phosphate concentrations (Pulido-Villena et al., 2013) increased soon after the dust additions. Dissolved iron concentrations decreased after the first dust addition, while increased after the second addition in the DUST Mesocosms, and remained stable in the CONTROL ones (Table 1; Wuttig et al., 2012). Silica concentrations were higher than the other macronutrients, and remained quite stable after dust additions (Table 1; Guieu et al., 2013).

\subsection{Phytoplankton biomass and community diversity}

In DUST Mesocosms (hereafter called DM), the first dust addition induced a picophytoplankton biomass increase (Chl $a_{<3}$; Fig. 1a), from $\sim 0.03$ to $\sim 0.06 \mu \mathrm{g} \mathrm{Chl} a_{<3} \mathrm{~L}^{-1}$, all over the three depths, reaching a maximal value of $0.056 \pm 0.018 \mu \mathrm{g} \mathrm{Chl} a_{<3} \mathrm{~L}^{-1}$ at the surface, five days after the first dust addition (Fig. 1a). In CONTROL Mesocosms (hereafter called CM), the $\mathrm{Chl} a_{<3}$ concentration was significantly lower than in DM $(p<0.01, n=114)$, ranging from $\sim 0.02$ to $\sim 0.03 \mu \mathrm{g} \mathrm{Chl} a_{<3} \mathrm{~L}^{-1}$ (Fig. 1b). The response of the nano- and microphytoplanktonic component ( $\left.\mathrm{Chl} a_{>3}\right)$ to the first dust addition was less strong than the picophytoplanktonic one, with $\mathrm{Chl} a_{>3}$ concentration slightly increasing from $\sim 0.014$ to $\sim 0.020 \mu \mathrm{g} \mathrm{Chl} a_{>3} \mathrm{~L}^{-1}$ (Fig. 1c).

After the second dust addition, the increase of Chl $a_{<3}$ biomass was strong (reaching $0.083 \pm 0.011 \mu \mathrm{g}$ Chl $\left.a_{<3} \mathrm{~L}^{-1}\right)$, mainly at the surface, while decreasing with depth (Fig. 1a) probably as a result of thermal stratification. The increase in $\mathrm{Chl} a_{>3}$ concentration was much more enhanced during the second dust addition (i.e., the day after 
(a) $\mathrm{Chl} \mathrm{a}(<3 \mu \mathrm{m})-\mathrm{DM}$

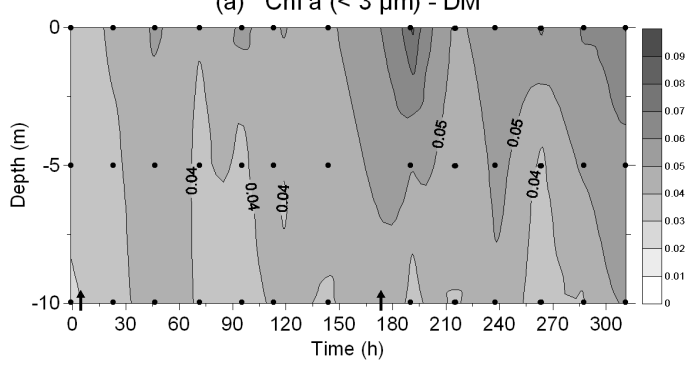

(c) $\mathrm{Chl} \mathrm{a}(>3 \mu \mathrm{m})-\mathrm{DM}$

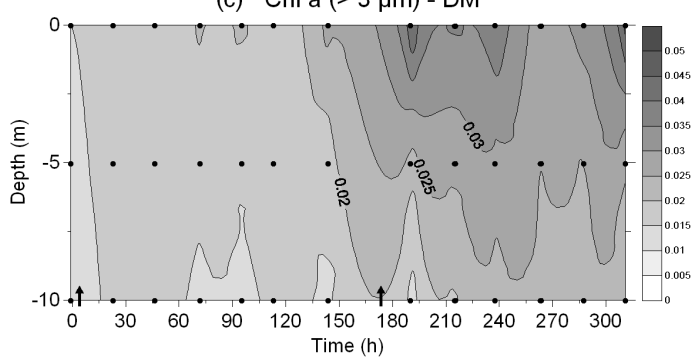

(e) $\mathrm{Chl} \mathrm{a}(<3 \mu \mathrm{m})$ : Chl a (Tot) - DM

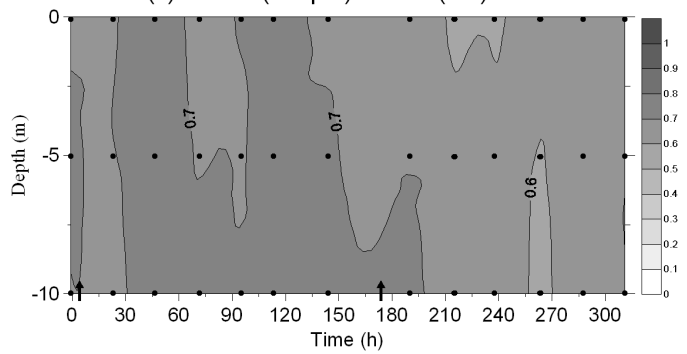

(b) $\mathrm{Chl} \mathrm{a}(<3 \mu \mathrm{m})-\mathrm{CM}$

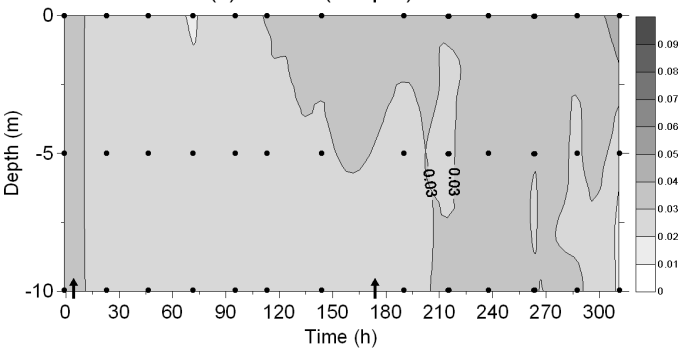

(d) $\mathrm{Chl} \mathrm{a}(>3 \mu \mathrm{m})-\mathrm{CM}$

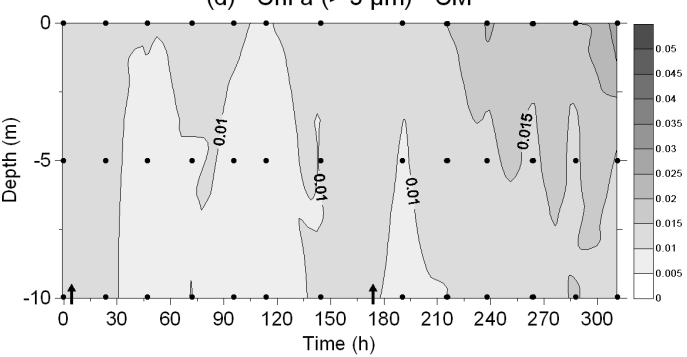

(f) $\mathrm{Chl} \mathrm{a}(<3 \mu \mathrm{m}): \mathrm{Chl}$ a $($ Tot $)-\mathrm{CM}$

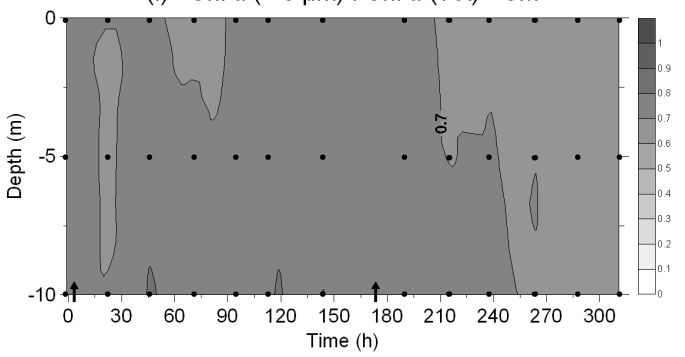

Fig. 1. Evolution of picophytoplankton mean chlorophyll (Chl) $a_{<3}$ concentration ( $\mu \mathrm{g} \mathrm{Chl} a_{<3} \mathrm{~L}^{-1}$ ) in dust-amended mesocosms (DM; (a) and control mesocosms (CM; (b), nano- and microphytoplankton mean Chl $a_{>3}$ concentration ( $\mu \mathrm{g}$ Chl $\left.a_{>3} \mathrm{~L}^{-1}\right)$ in DM (c) and CM (d), and picophytoplankton biomass contribution to total phytoplankton biomass (Chl $a_{<3}$ : Chl $a_{\mathrm{Tot}}$ ) in DM (e) and CM (f), over time (hours). The arrows indicate the time at which each dust addition was performed.

the addition) relative to the first one, all over the depth gradient, but especially at the surface (reaching $0.046 \pm 0.002 \mu \mathrm{g}$ Chl $a_{>3} \mathrm{~L}^{-1}$; Fig. 1c).

Seasonal transition changes in water temperature (from 2 July onward; Table 1) might explain the increase in $\mathrm{Chl} a_{<3}$ and $\mathrm{Chl} a_{>3}$ concentration found in $\mathrm{CM}$ after the second dust addition (Fig. 1b, d), in agreement with the well known influence of temperature on the growth rate of phytoplankton (see Chen and Liu, 2010, and references therein).

Picophytoplankton accounted for $\sim 70 \%$ of total phytoplankton biomass, in both $\mathrm{DM}$ and $\mathrm{CM}$, remaining almost stable during the entire experiment, while decreasing to $\sim 60 \%$ after the second dust addition, only in DM (Fig. 1e, f).

Concerning the contribution of phytoplankton groups on the two size classes, we performed multiple regressions on the entire dataset (i.e., samples taken soon before and after each dust addition) between the measured $\mathrm{Chl} a$ concentra- tion of the two size classes and the Chl $a$ concentration of the specific groups (retrieved from ChemTax analysis):

$$
\begin{aligned}
\text { Chl } a_{<3} & =0.04_{\text {Prasinophyceae }}+0.107_{\text {Dinophyceae }} \\
& +0.535_{\text {Haptophyceae }}+0.270_{\text {Pelagophyceae }} \\
& +0.566_{\text {Cyanophyceae }}+0.058_{\text {Bacillariophyceae }}
\end{aligned}
$$

Chl $a_{>3}=0.007_{\text {Prasinophyceae }}+0.228_{\text {Dinophyceae }}$

$$
\begin{aligned}
& +0.310_{\text {Haptophyceae }}+0.406_{\text {Chlorophyceae }} \\
& +0.077_{\text {Cyanophyceae }}+0.233_{\text {Bacillariophyceae }}
\end{aligned}
$$

Picophytoplanktonic diversity (in terms of Chl $a_{<3}$ concentration) was mainly dominated by Cyanophyceae, Haptophyceae and Pelagophyceae $\left(n=113, R^{2}=0.99\right.$, $p<0.001$ ), while Chlorophyceae, Haptophyceae, Bacillariophyceae and Dinophyceae, were the dominant groups for the nano- and microphytoplanktonic component $(n=114$, $\left.R^{2}=0.99, p<0.001\right)$. 
Table 1. Evolution of environmental conditions during the experiment, and initial environmental conditions. Temperature $\left({ }^{\circ} \mathrm{C}\right)$, light $(\mu \mathrm{mol}$ photons $\left.\mathrm{m}^{-2} \mathrm{~s}^{-1}\right)$, daily integrated light (mol photons $\left.\mathrm{m}^{-2} \mathrm{~d}^{-1}\right)$, nitrate $\left(\mathrm{NO}_{3}^{-}, \mu \mathrm{M}\right)$, nitrite $\left(\mathrm{NO}_{2}^{-}, \mu \mathrm{M}\right)$, dissolved inorganic phosphorus (DIP, nmol L $\left.{ }^{-1}\right)$, orthosilicic acid $\left(\mathrm{Si}(\mathrm{OH})_{4}, \mu \mathrm{mol} \mathrm{L}{ }^{-1}\right)$, dissolved iron $\left(\mathrm{DFe}, \mathrm{nmol} \mathrm{L}^{-1}\right)$, bacteria abundance $\left(10^{5} \mathrm{cells}^{\mathrm{mL}} \mathrm{L}^{-1}\right)$. ${ }^{*} \mathrm{Temper}-$ ature mean data \pm SD over 24 h. ** Light measurements between 04:05 a.m. and 11:00 p.m., with the only exception of 9 July (i.e., between 04:05 a.m. and 03:00 p.m.). Data are mean $(n=7) \pm$ SD (Wuttig et al., 2012; Guieu et al., 2013; Pulido-Villena et al., 2013; Ridame et al., 2013).

\begin{tabular}{llll}
\hline & & \multicolumn{2}{c}{ Evolution of environmental conditions } \\
\hline & First dust addition & Second dust addition & End of the experiment \\
\hline Stratification & No stratification & $5^{\circ} \mathrm{C}$ between -0.1 and $-10 \mathrm{~m}$ & $5^{\circ} \mathrm{C}$ between -0.1 and $-10 \mathrm{~m}$ \\
Temperature $($ at $-5 \mathrm{~m}$ depth)* & $21.07 \pm 0.22$ & $21.67 \pm 0.46$ & $23.63 \pm 0.64$ \\
Maximal light of the day & 890.00 & 873.77 & 841.82 \\
Daily integrated light (at $-0.1 \mathrm{~m}$ depth)** & 21.33 & 21.12 & 23.50 \\
\hline & \multicolumn{1}{c}{ Initial environmental conditions (mean of DM, CM, and OutM concentrations) } \\
\hline & $-0.1 \mathrm{~m}$ & $-5 \mathrm{~m}$ & $-10 \mathrm{~m}$ \\
\hline $\mathrm{NO}-$ & $\leq 0.03 \mu \mathrm{M}(\mathrm{d} .1)$. & $\leq 0.03 \mu \mathrm{M}(\mathrm{d} .1)$. & $\leq 0.03 \mu \mathrm{M}(\mathrm{d} .1)$. \\
$\mathrm{NO}$ & $\leq 0.01 \mu \mathrm{M}(\mathrm{d} .1)$. & $\leq 0.01 \mu \mathrm{M}(\mathrm{d} .1)$. & $\leq 0.01 \mu \mathrm{M}(\mathrm{d} .1)$. \\
$\mathrm{DIP}$ & $3 \pm 2$ & $7 \pm 2$ & $5 \pm 2$ \\
$\mathrm{Si}(\mathrm{OH})_{4}$ & $1.15 \pm 0.01$ & $1.26 \pm 0.19$ & $1.26 \pm 0.20$ \\
$\mathrm{DFe}$ & $3.58 \pm 0.64$ & $3.87 \pm 0.66$ & $2.65 \pm 0.36$ \\
$\mathrm{Bacteria}$ abundance & $4.8 \pm 0.3$ & $4.7 \pm 0.4$ & $4.3 \pm 0.4$ \\
\hline
\end{tabular}

Haptophyceae, Cyanophyceae and Pelagophyceae were the most represented picoplanktonic taxonomic groups, all responding to the dust additions (Fig. 2). Even if less abundant, Prasinophyceae, Dinophyceae and Bacillariophyceae were also present (data not shown).

Before the first dust addition, Haptophyceae were the main contributor to the $\mathrm{Chl} a_{<3}$ concentration, with an initial Chl $a_{<3}$ concentration of $\sim 0.014 \mu \mathrm{g}$ Chl $a_{<3} \mathrm{~L}^{-1}$ (Fig. 2a, b). The biomass of this group increased (up to $0.028 \pm 0.003 \mu \mathrm{g}$ Chl $a_{<3} \mathrm{~L}^{-1}$; Fig. 2a) five days after the first dust addition, while it quickly responded to the second addition, reaching $0.039 \pm 0.005 \mu \mathrm{g} \mathrm{Chl} a_{<3} \mathrm{~L}^{-1}$. In CM, the biomass values of Haptophyceae were significantly lower than the DM ones $(p<0.01, n=112)$, ranging between $\sim 0.006$ and $\sim 0.020 \mu \mathrm{g} \mathrm{Chl} a_{<3} \mathrm{~L}^{-1}$ (Fig. 2b).

The initial $\mathrm{Chl} a_{<3}$ concentration of Cyanophyceae $\left(0.010 \pm 0.004 \mu \mathrm{g} \mathrm{Chl} a_{<3} \mathrm{~L}^{-1}\right)$ increased at the surface in response to the first $\left(0.020 \pm 0.004 \mu \mathrm{g} \mathrm{Chl} a_{<3} \mathrm{~L}^{-1}\right)$ and second dust addition (0.024 $\pm 0.008 \mu \mathrm{g} \mathrm{Chl} a_{<3} \mathrm{~L}^{-1}$; Fig. 2c). An increase in the biomass of Cyanophyceae can be noticed at the end of the experiment $\left(\sim 0.030 \mu \mathrm{g} \mathrm{Chl} a_{<3} \mathrm{~L}^{-1}\right.$; Fig. 2c). In CM, the biomass of Cyanophyceae was significantly lower than in $\mathrm{DM}(p<0.01, n=112)$, and ranged between $\sim 0.003$ and $\sim 0.012 \mu \mathrm{g} \mathrm{Chl} a_{<3} \mathrm{~L}^{-1}$, with no peculiar trend over time (Fig. 2d).

The initial Chl $a_{<3}$ concentration of Pelagophyceae was $\sim 0.008 \mu \mathrm{g} \mathrm{Chl} a_{<3} \mathrm{~L}^{-1}$ (Fig. 2e, f) and it increased especially at the surface, after the first $(0.015 \pm 0.003 \mu \mathrm{g}$ $\left.\mathrm{Chl} a_{<3} \mathrm{~L}^{-1}\right)$ and second dust addition $(0.016 \pm 0.002 \mu \mathrm{g}$ $\mathrm{Chl} a_{<3} \mathrm{~L}^{-1}$; Fig. 2e). In CM, the biomass of Pelagophyceae was significantly lower than in DM ( $\mathrm{p}<0.01, n=112)$, and ranged between $\sim 0.004$ and $\sim 0.012 \mu \mathrm{g} \mathrm{Chl} a_{<3} \mathrm{~L}^{-1}$, without any specific trend over time and depth gradients (Fig. 2f).

Haptophyceae, Chlorophyceae and Bacillariophyceae were the most represented groups in terms of nano- and microphytoplankton biomass, with lower biomass contribution from other groups (e.g., Prasinophyceae, Dinophyceae; data not shown).

The biomass of nano- and micro-Haptophyceae (Chl $a_{>3}$ concentration) mainly increased after the second dust addition (from $\sim 0.008$ to $\sim 0.015 \mu \mathrm{g} \mathrm{Chl} a_{>3} \mathrm{~L}^{-1}$ ), whereas slightly increasing after the first addition (Fig. 3a). In CM, the biomass of Haptophyceae was significantly lower than in DM $(p<0.01, n=111)$, and relatively stable over time and depth gradients (Fig. 3b), with the only exception of the slight biomass increase concomitant to the thermal stratification of the water column, at the end of the experiment.

The biomass of Bacillariophyceae was very low and it slightly increased after the first dust addition from $\sim 0.0009$ to $\sim 0.0020 \mu \mathrm{g} \mathrm{Chl} a_{>3} \mathrm{~L}^{-1}$, whereas their greatest increase was found five-six days after the second addition, especially below $5 \mathrm{~m}\left(0.0092 \pm 0.004 \mu \mathrm{g} \mathrm{Chl} a_{>3} \mathrm{~L}^{-1}\right.$; Fig. 3c). In $\mathrm{CM}$, the biomass of Bacillariophyceae was significantly lower than in DM ( $p<0.01, n=111$; Fig. $3 \mathrm{~d})$, following the same positive trend as described previously for Haptophyceae biomass (Fig. 3b).

Chlorophyceae were only present in DM (Fig. 3e), underlining a very strong nutrient limitation for growth in control conditions (Fig. 3f), as well as their possible opportunistic strategy in response to nutrient availability. Their $\mathrm{Chl} a_{>3}$ 

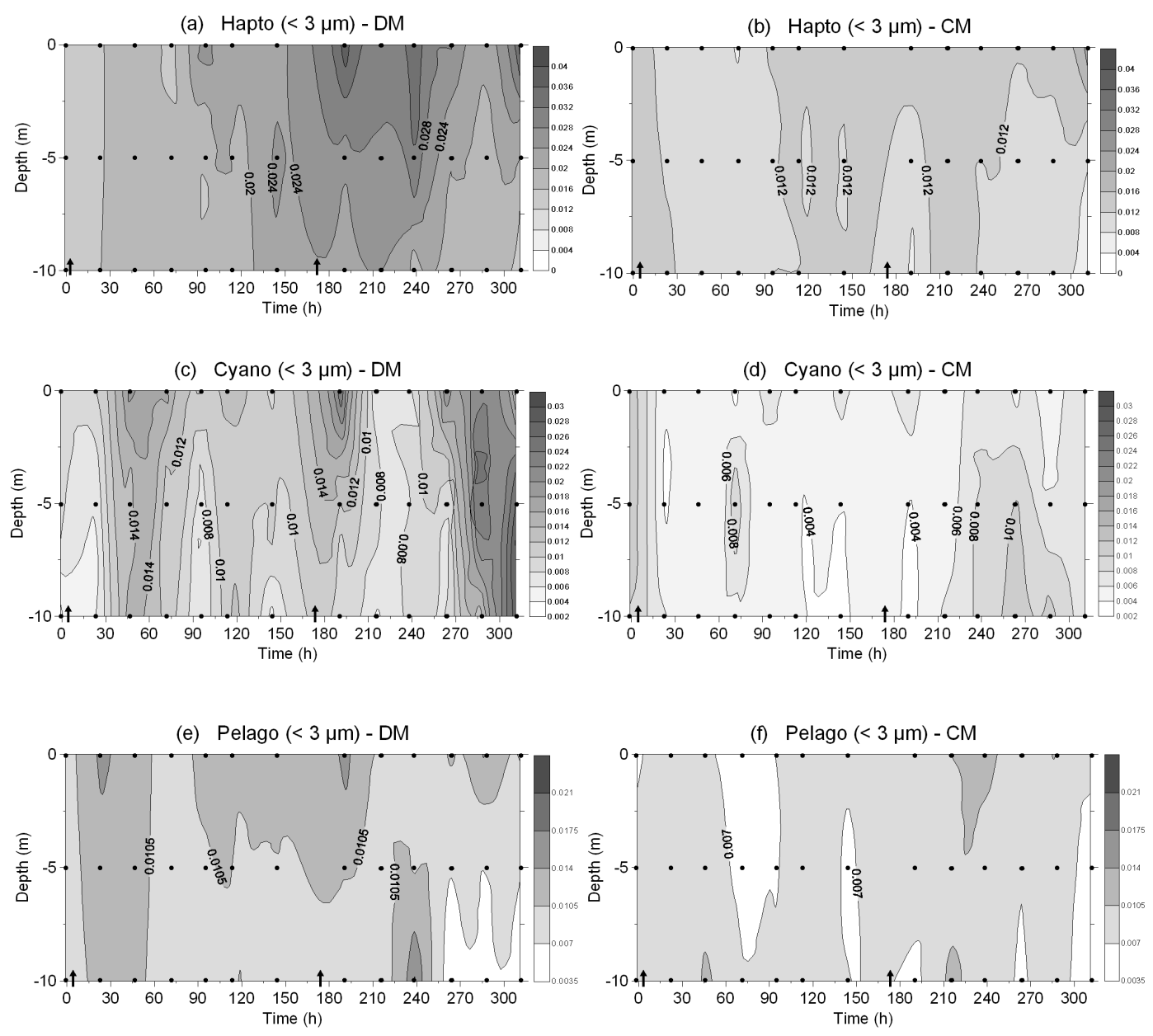

Fig. 2. Evolution of picophytoplanktonic Haptophyceae mean chlorophyll (Chl) $a_{<3}$ concentration ( $\mu$ g Chl $a_{<3} \mathrm{~L}^{-1}$ ) in dust-amended mesocosms (DM; (a) and control mesocosms (CM; (b), Cyanophyceae mean Chl $a_{<3}$ concentration $\left(\mu \mathrm{g} \mathrm{Chl} a_{<3} \mathrm{~L}^{-1}\right)$ in DM (c) and CM (d), and Pelagophyceae mean Chl $a_{<3}$ concentration ( $\mu \mathrm{g} \mathrm{Chl} a_{<3} \mathrm{~L}^{-1}$ ) in DM (e) and CM (f), over time (hours). The biomass of each picophytoplanktonic group was obtained through ChemTax analysis. Cyano, Cyanophyceae; Hapto, Haptophyceae; Pelago, Pelagophyceae. The arrows indicate the time at which each dust addition was performed.

concentration doubled mainly at the surface (from $\sim 0.007$ to $\sim 0.013 \mu \mathrm{g} \mathrm{Chl} a_{>3} \mathrm{~L}^{-1}$ ) just after the second dust addition took place (Fig. 3e).

\subsection{Phytoplankton abundances by flow cytometry measurements}

Synechococcus was the dominant picophytoplankton in terms of cellular abundance. In DM, Synechococcus cellular abundance remained almost stable $\left(\sim 20.000\right.$ cells $\left.\mathrm{mL}^{-1}\right)$ after the first dust addition, while it significantly increased after the second dust addition $(p<0.01, n=54)$, reaching a value of $41.806 \pm 3965 \mathrm{cell} \mathrm{mL}^{-1}$, at the end of the experiment (Fig. 4a). It can be noticed that the maximal Synechococcus cellular abundance was found below the $5 \mathrm{~m}$ depth. In CM, Synechococcus cellular abundance was significantly lower than in $\mathrm{DM}(p<0.01, n=117$; Fig. $4 \mathrm{~b})$, increasing from the middle of the experiment, as the $\mathrm{Chl} a_{<3}$ concentration did.
Prochlorococcus cellular abundance was very low, ranging between $\sim 500$ and $\sim 2500$ cell mL $^{-1}$, confirming the lack of detection of divinyl-chlorophyll $a$ pigment by HPLC analysis. No significant changes occurred in relation to dust additions (data not shown).

Picoeukaryotes represented the least abundant picophytoplanktonic component, with a cellular abundance ranging between $\sim 70$ and $\sim 470$ cell $\mathrm{mL}^{-1}$ (Fig. $4 \mathrm{c}$, d), without being significantly affected by dust additions ( $p>0.05, n=117)$.

The cellular abundance of nanophytoplankton increased soon after the second dust addition from $\sim 500$ to $\sim 950$ cell $\mathrm{mL}^{-1}$, especially at the surface, reaching a maximal value of $1351 \pm 306$ cell $\mathrm{mL}^{-1}$ on the last day of the experiment (Fig. 4e). In CM, the nanophytoplankton cellular abundance was significantly lower than in DM $(p<0.01$, $n=117$; Fig. 4f), and increased over the three depths (from 

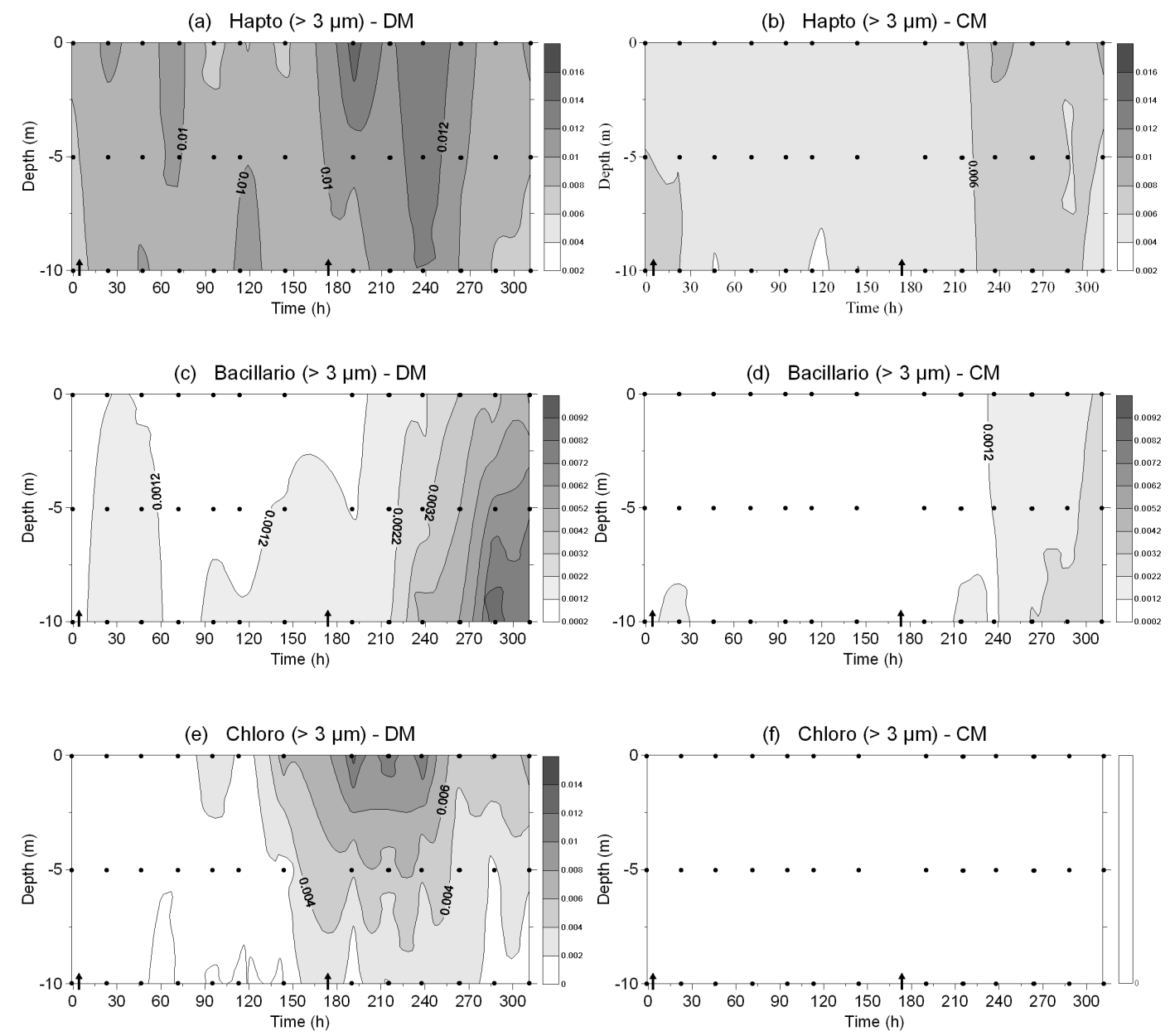

Fig. 3. Evolution of nano- and microphytoplanktonic Haptophyceae mean chlorophyll (Chl) $a_{>3}$ concentration $\left(\mu \mathrm{g}\right.$ Chl $\left.a_{>3} \mathrm{~L}^{-1}\right)$ in dustamended mesocosms (DM; (a) and control mesocosms (CM; (b), Bacillariophyceae mean Chl $a_{>3}$ concentration $\left(\mu \mathrm{g} \mathrm{Chl} a_{>3} \mathrm{~L}^{-1}\right)$ in DM (c) and CM (d), and Chlorophyceae mean Chl $a_{>3}$ concentration ( $\mu \mathrm{g} \mathrm{Chl} a_{>3} \mathrm{~L}^{-1}$ ) in DM (e) and CM (f), over time (hours). The biomass of each nano- and microphytoplanktonic group was obtained through ChemTax analysis. Bacillario, Bacillariophyceae; Chloro, Chlorophyceae; Hapto, Haptophyceae. The arrows indicate the time at which each dust addition was performed.

$\sim 300$ to $\sim 600$ cell $\mathrm{mL}^{-1}$; Fig. $4 \mathrm{f}$ ), starting from the middle of the experiment.

Multiple regressions were performed on the complete dataset (i.e., samples taken soon before and after each dust addition) between cellular abundance and Chl $a$-group specific concentration values. For the picophytoplankton community, none of the tested multiple regressions was significant, probably suggesting a huge diversity in pigment content of the distinct groups alternating during the experiment. By contrast, for the nanophytoplankton community, the following result was obtained $\left(\mathrm{n}=112, R^{2}=0.52, p<0.001\right)$ :

$$
\begin{aligned}
& \text { Nano Cell Abundance }=0.322_{\text {Dinophyceae }} \\
& +0.349_{\text {Haptophyceae }}+0.203_{\text {Chlorophyceae }} \\
& +0.267_{\text {Bacillariophyceae }}
\end{aligned}
$$

The highest pigment contribution to cellular abundance was due to Haptophyceae, followed by Dinophyceae, Bacillariophyceae and lastly Chlorophyceae, a finding that might highlight the distinct $\mathrm{Chl} a$ cellular content among these groups, in relation to their different cell size.

By reporting pigment data per cellular abundance data, we are able to describe few specific physiological changes of the phytoplanktonic community.

Zeaxanthin (Zeax) per Synechococcus cell increased after the first dust addition (from $\sim 0.5$ to $\sim 1.3$ fg Zeax cell ${ }^{-1}$ ), and after the second addition only at the surface (from $\sim 0.6$ to $\sim 1 \mathrm{fg}$ Zeax cell ${ }^{-1}$, Fig. 5a), with values lower than $0.7 \mathrm{fg}$ Zeax cell ${ }^{-1}$ in CM (Fig. 5b).

An almost two-fold increase in Chl $a_{<3}$ concentration per picophytoplankton cell (from $\sim 1.5$ to $\sim 3 \mathrm{fg} \mathrm{Chl} a_{<3}$ cell $^{-1}$ ) rapidly occurred after the first dust addition, mainly at the surface, suggesting a very fast physiological response 

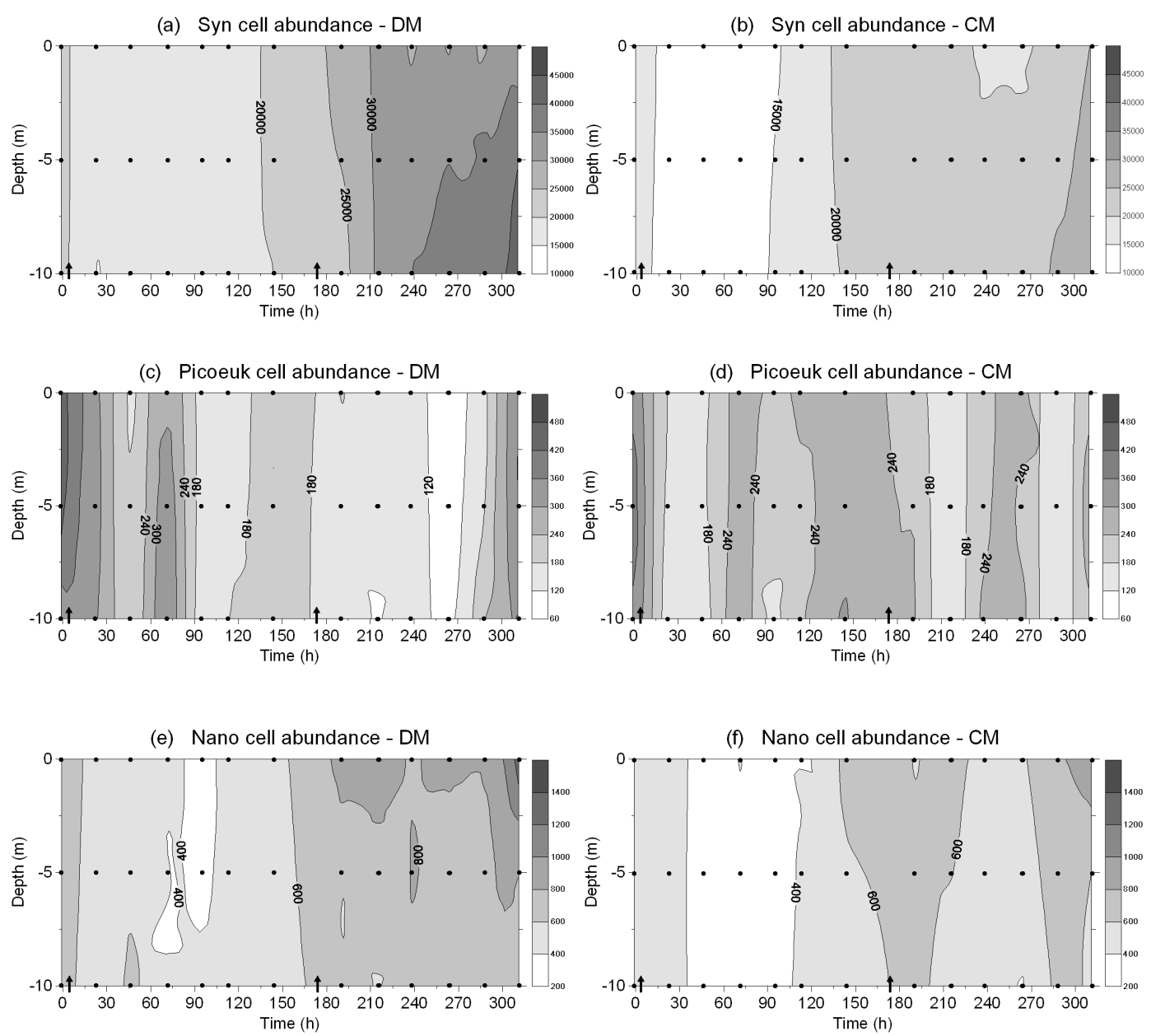

Fig. 4. Evolution of Synechococcus mean cell abundance (cells $\left.\mathrm{mL}^{-1}\right)$ in dust-amended mesocosms (DM; (a) and control mesocosms (CM; (b), picoeukaryotes mean cell abundance (cells $\mathrm{mL}^{-1}$ ) in DM (c) and CM (d), and nanophytoplankton mean cell abundance (cells $\mathrm{mL}^{-1}$ ) in DM (e) and CM (f), over time (hours). Syn, Synechococcus; Picoeuk, picoeukaryotes; Nano, nanophytoplankton. The arrows indicate the time at which each dust addition was performed.

of picophytoplankton to the input of new nutrients (Fig. 5c). This response lasted for some days before decreasing, and increased again after the second dust addition $(\sim 3 \mathrm{fg}$ Chl $a_{<3}$ cell $\left.^{-1}\right)$. In CM, the Chl $a_{<3}$ concentration per picophytoplankton cell was lower than $2.0 \mathrm{fg} \mathrm{Chl} a_{<3}$ cell $^{-1}$ (Fig. 5d).

Chl $a_{>3}$ concentration per nanophytoplankton cell ranged from $\sim 20 \mathrm{fg} \mathrm{Chl} a_{>3}$ cell $^{-1}$ to a maximal value of $60 \pm 10 \mathrm{fg}$ Chl $a_{>3}$ cell $^{-1}$ (Fig. 5e), quickly increasing the day after each dust addition $\left(\sim 40 \mathrm{fg} \mathrm{Chl} a_{>3}\right.$ cell $^{-1}$, and $\sim 48 \mathrm{fg}$ Chl $a_{>3}$ cell $^{-1}$, after the first and second dust addition, respectively; Fig. 5e). In CM, the $\mathrm{Chl} a_{>3}$ cell $^{-1}$ remained low, ranging between $\sim 13$ and $\sim 28 \mathrm{fg} \mathrm{Chl} a_{>3}$ cell $^{-1}$ (Fig. 5f).

\subsection{Photosynthetic parameters and photoprotective responses}

One of the most intriguing results we obtained is the absence of response of the PAM-estimated photosynthetic parame- ters to dust additions, relative to control conditions. The photosynthetic parameters, electron transport rate $\left(\mathrm{rel}_{\mathrm{eTR}} \max \right)$, quantum yield of electron transport $\left(\mathrm{rel}^{\mathrm{B}} \alpha^{\mathrm{B}}\right)$ and light saturation index (Ek), were almost stable over time, with similar values among DM and CM (Fig. 6).

New nutrient inputs induced also changes in the modulation of non-photochemical fluorescence quenching (NPQ) and xanthophyll cycle (XC). NPQ increased after the first dust addition, reaching the value of $\sim 0.28$ (from a very low initial value of $\sim 0.006$; Fig. 7a). After the second dust addition, NPQ is further enhanced, up to a surface value of $\sim 0.48$, probably in relation to the higher biomass contribution of nano- and microphytoplankton than after the first addition (Fig. 7a). In CM, NPQ was significantly lower than in DM ( $p<0.01, n=79$; Fig. 7b), and increased at the end of the experiment, in relation with the slight nano- and microphytoplankton biomass augment. 
(a) Zeax $(<3 \mu \mathrm{m})$ : Syn cell - DM

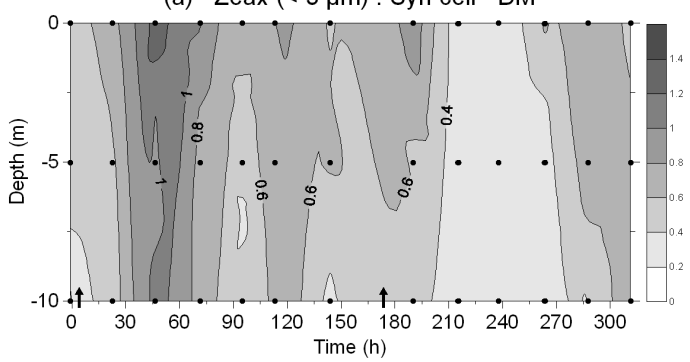

(c) Chl a $(<3 \mu \mathrm{m})$ : Pico cell - DM

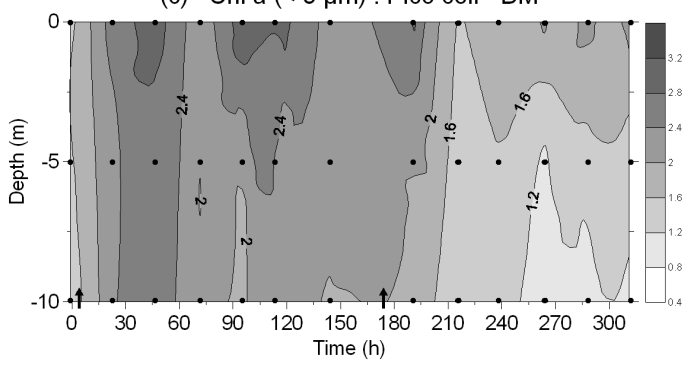

(e) Chl a $(>3 \mu \mathrm{m})$ : Nano cell - DM

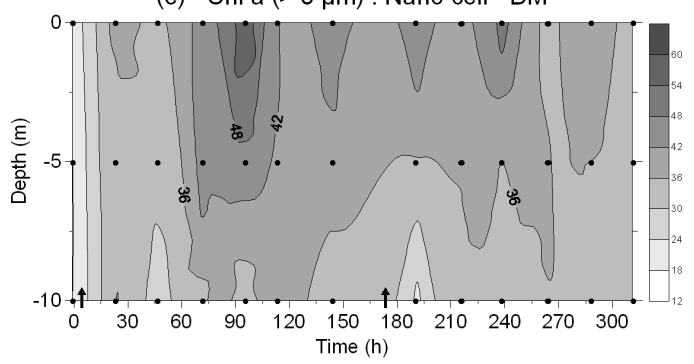

(b) Zeax $(<3 \mu \mathrm{m})$ : Syn cell - CM

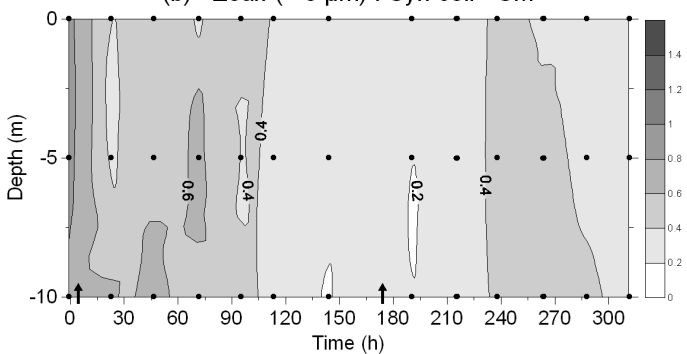

(d) Chl a $(<3 \mu \mathrm{m})$ : Pico cell - CM

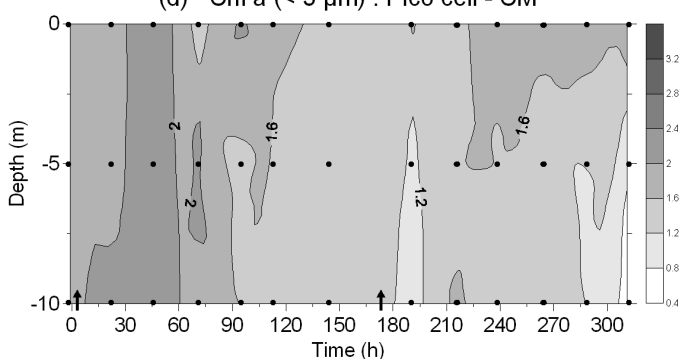

(f) Chl a $(>3 \mu \mathrm{m})$ : Nano cell - CM

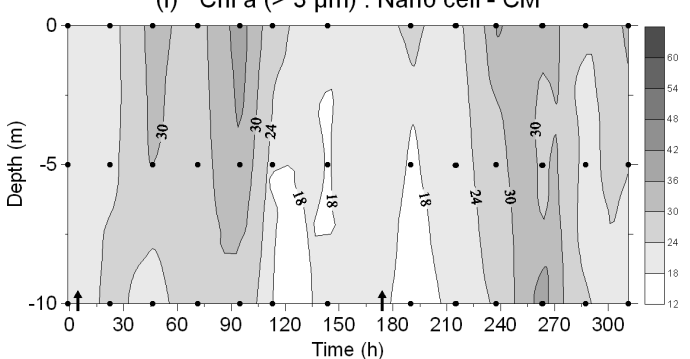

Fig. 5. Evolution of picophytoplankton mean zeaxanthin $\left(Z_{e a x}<3\right)$ concentration per Synechococcus cell $\left(f g\right.$ Zeax $_{<3}$ cell $\left.^{-1}\right)$ in dustamended mesocosms (DM; (a) and control mesocosms (CM; (b), picophytoplankton mean chlorophyll (Chl) $a_{<3}$ concentration per the sum of Synechococcus and picoeukaryotes cell (fg Chl $a_{<3}$ cell $^{-1}$ ) in DM (c) and CM (d), and nanophytoplankton mean Chl $a_{>3}$ concentration per cell (fg Chl $a_{>3}$ cell $^{-1}$ ) in DM (e) and CM (f), over time (hours). Syn, Synechococcus; Pico, picophytoplankton; Nano, nanophytoplankton.The arrows indicate the time at which each dust addition was performed.

Diadinoxanthin (Dd) and diatoxanthin (Dt) $\mathrm{Chl} a^{-1}$ ratios were generally higher in DM than in CM, even if sometimes undetectable by HPLC, due to volume-fractionation of samples (data not shown).

\subsection{Phytoplankton biomass increase vs. nutrient conditions}

In this section, we aim at relating the increase of Chl $a$ concentration observed after dust additions with the use of nutrient, on a daily basis. We chose three days in which phytoplankton biomass increased just after the dust additions, and assumed that the impact of grazing or cell death was negligible. Daily variations of $\mathrm{Chl} a$ concentration and nutrient concentration were calculated on mean data measured at -0.1 and $-5 \mathrm{~m}$ depths, being more homogeneous than data collected at $-10 \mathrm{~m}$ (mainly after the second dust addition).
The increase in Chl $a$ concentration per day ( $\mu \mathrm{g}$ Chl $a \mathrm{~L}^{-1} \mathrm{~d}^{-1}$ ) for the two phytoplankton size classes, and the relative decrease in nutrient concentration ( $\mu \mathrm{g}$ nutrient $\mathrm{L}^{-1} \mathrm{~d}^{-1}$ ), after dust additions, are reported in Table 2 .

Two days after the first dust addition, i.e., after one lag day, only the picophytoplankton was able to increase their $\mathrm{Chl} a$ biomass, mainly with an increase in Cyanophyceae $(\sim 77 \%)$ and Haptophyceae $(\sim 23 \%)$, while nano- and microphytoplankton biomass increased three days after this dust addition (Table 2). By comparing biomass and nutrient variations, two and three days after the first dust addition, nano- and microphytoplankton would need similar $\left[\mathrm{NO}_{3}^{-}\right]$and $\left[\mathrm{PO}_{4}^{3-}\right]$, but almost two-fold lower $\left[\mathrm{Si}(\mathrm{OH})_{4}\right]$, and four-fold higher [DFe], than the picophytoplankton, to reach the same daily biomass augment. A similar $\left[\mathrm{NO}_{3}^{-}\right]$need for the two size classes of phytoplankton was quite unexpected. We can hypothesise that nano- and microphytoplankton underwent nitrogen and 

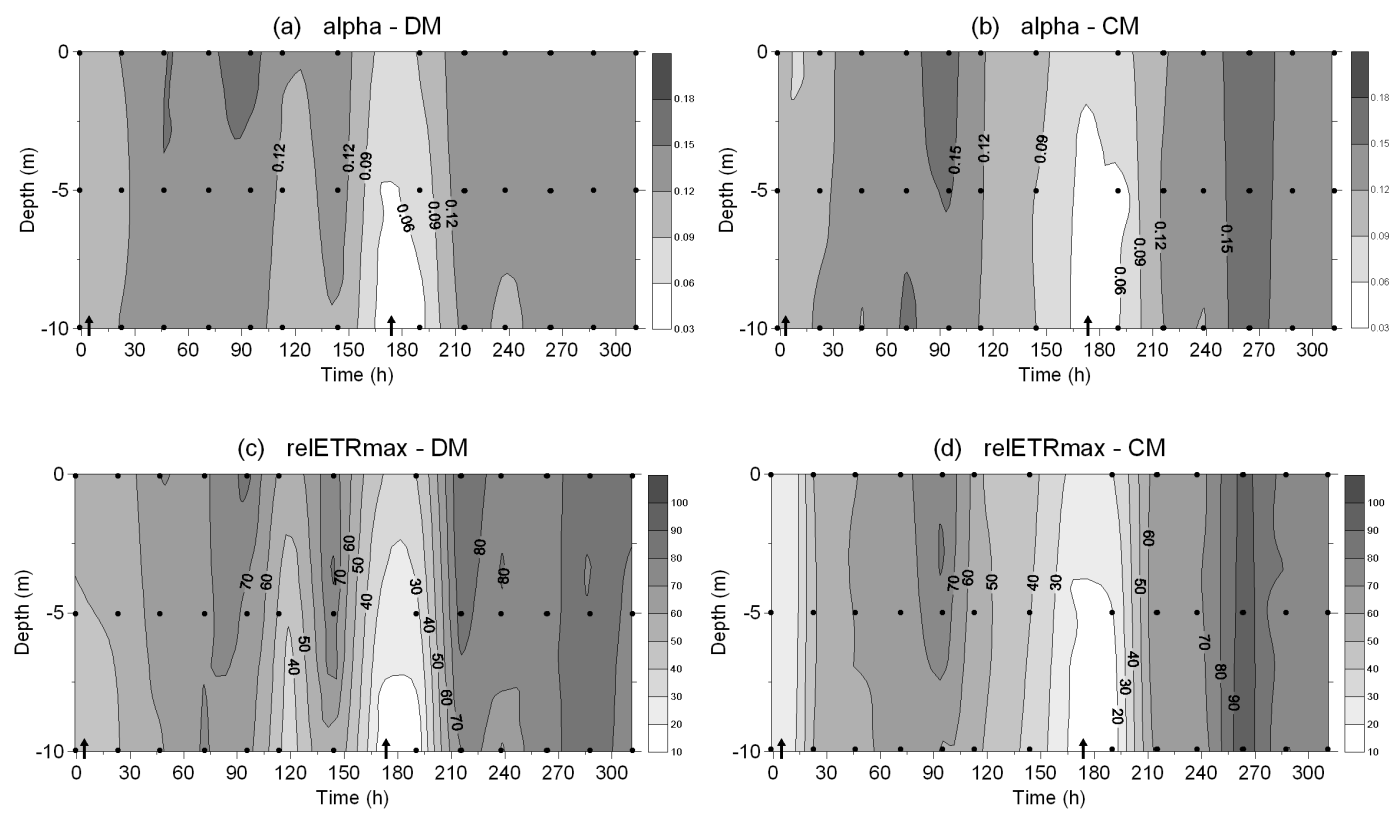

(e) Ek - DM
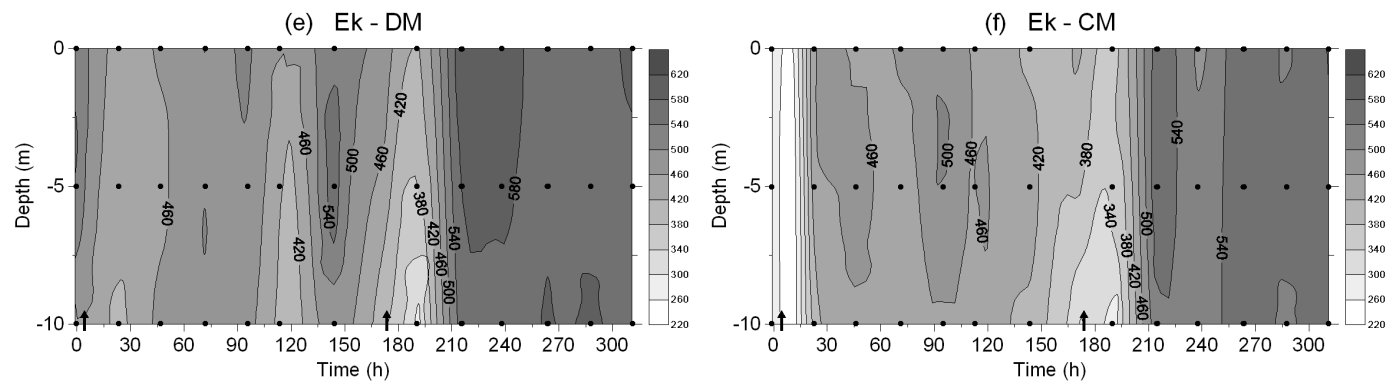

Fig. 6. Evolution of the quantum yield of electron transport $\left(\mathrm{rel}^{\mathrm{B}} ; \mu \mathrm{mol} \mathrm{e}^{-} \mathrm{m}^{-2} \mathrm{~s}^{-1}\left[\mu \mathrm{mol} \text { photons } \mathrm{m}^{-2} \mathrm{~s}^{-1}\right]^{-1}\right)$ in dust-amended mesocosms (DM; (a) and control mesocosms (CM; (b), relative electron transport rate $\left(\right.$ relETR $\left.E_{\max } ; \mu \mathrm{mol} \mathrm{e}^{-} \mathrm{m}^{-2} \mathrm{~s}^{-1}\right)$ in DM (c) and CM (d), and light saturation index (Ek; $\mu$ mol photons $\left.\mathrm{m}^{-2} \mathrm{~s}^{-1}\right)$ in DM (e) and CM (f), over time (hours). The arrows indicate the time at which each dust addition was performed.

phosphate colimitation in their initial response to the first dust addition, in agreement with the available very low nitrate concentration (see Ridame et al., 2013).

The response of the phytoplankton community to the second dust addition occurred the day after the pulse of new nutrients (i.e., 191 h) and was much stronger than after the first dust addition, with an almost three-fold higher $\mathrm{Chl} a_{\mathrm{Tot}}$ increase (0.0271 $\mu \mathrm{g} \mathrm{Chl} a_{\mathrm{Tot}} \mathrm{L}^{-1} \mathrm{~d}^{-1}$ at $191 \mathrm{~h}$; Table 2), relative to the first addition $\left(0.0091 \mu \mathrm{g} C h l a_{\mathrm{Tot}} \mathrm{L}^{-1} \mathrm{~d}^{-1}\right.$ at 23h; data not shown). During the second dust addition, a $48 \%$ contribution to total biomass increase was due to nanoand microphytoplankton (Table 2), i.e., a higher contribution relative to their percentage after the first dust addition (35\%; data not shown), consistently with the greater use of $\left[\mathrm{NO}_{3}^{-}\right]$and $\left[\mathrm{PO}_{4}^{3-}\right]$ (Table 2), which agrees with the nutrient repletion of the day after the dust deposition. The nano- and microphytoplankton biomass increase was mainly due to Haptophyceae and Chlorophyceae, whereas the increase in picophytoplankton biomass mainly to Haptophyceae and Cyanophyceae (Table 2).

\section{Discussion}

\subsection{Changes in the structure and composition of the phytoplankton community in response to dust additions}

The aim of this study was to investigate how atmospheric new nutrient pulses affect the growth of the surface water layer phytoplankton community of a LNLC area of the Mediterranean Sea, by coupling the study of functional features, such as cell size or photobiological properties, with a size-dependent chemotaxonomic pigment analysis (Rodriguez et al., 2006; Not et al., 2007). The dependency on micro-algal cell size of the ecosystem structure and functioning is well known, and the contribution of the HPLC 
Table 2. Daily variation of total and fractionated chlorophyll (Chl) $a$ concentration ( $\left.\mu \mathrm{g} \mathrm{Chl} a \mathrm{~L}^{-1} \mathrm{~d}^{-1}\right)$, dominant phytoplanktonic groups ( $\left.\mu \mathrm{g} \mathrm{Chl} a \mathrm{~L}^{-1} \mathrm{~d}^{-1}\right)$, and nutrients concentration ( $\mu \mathrm{g}$ nutrient $\left.\mathrm{L}^{-1} \mathrm{~d}^{-1}\right)$ in dust-amended mesocosms $(\mathrm{DM})$, two $(47 \mathrm{~h})$ and three days $(71 \mathrm{~h})$ after the first dust addition, and the day after the second dust addition (191 hours). $\Delta\left[\right.$ Chl $\left.a_{\text {Tot }}\right]$, variation of total chlorophyll $a$ concentration; $\Delta \mathrm{Chl} a_{<3}$, variation of picophytoplankton chlorophyll $a$ concentration; $\Delta$ [Chl $a_{>3}$ ], variation of nano-/microphytoplankton chlorophyll $a$ concentration. Daily variations have been calculated on mean values of the data measured at -0.1 and $-5 \mathrm{~m}$ depths. Chloro, Chlorophyceae; Cyano, Cyanophyceae; Dino, Dinophyceae; Hapto, Haptophyceae; Pelago, Pelagophyceae. $\mathrm{NO}_{3}^{-}$, nitrate; $\mathrm{NO}_{2}^{-}$, nitrite; $\mathrm{PO}_{4}^{3-}$, phosphate; $\mathrm{Si}(\mathrm{OH})_{4}$, orthosilicic acid; DFe, dissolved iron.

\begin{tabular}{|c|c|c|c|c|c|c|c|c|}
\hline Time & $\Delta\left[\right.$ Chl $\left.a_{\text {Tot }}\right]$ & $\Delta\left[\right.$ Chl $\left.a_{<3}\right]$ & $\Delta\left[\mathrm{Chl} a_{>3}\right]$ & $\Delta \mathrm{NO}_{3}^{-}$ & $\Delta \mathrm{PO}_{4}^{3-}$ & $\Delta \mathrm{NO}_{2}^{-}$ & $\Delta \mathrm{Si}(\mathrm{OH})_{4}$ & $\Delta \mathrm{DFe}$ \\
\hline \multicolumn{9}{|c|}{ First dust addition } \\
\hline 47 & 0.0077 & $\begin{array}{r}0.0077 \\
\text { Hapto }_{<3}(23 \%) \\
\text { Cyano }_{<3}(77 \%)\end{array}$ & 0.000 & -38.1 & -0.46 & -0.67 & -12.3 & -0.035 \\
\hline 71 & -0.0058 & -0.0085 & $\begin{array}{r}0.0027 \\
\text { Dino }_{>}(55 \%) \\
\text { Hapto }_{>}(45 \%)\end{array}$ & -15.5 & -0.17 & -0.14 & -2.31 & -0.042 \\
\hline \multicolumn{9}{|c|}{ Second dust addition } \\
\hline 191 & 0.027 & $\begin{array}{r}0.0157 \\
\text { Hapto }_{<3}(51 \%) \\
\text { Cyano }_{<3}(36 \%) \\
\text { Pelago }_{<3}(13 \%)\end{array}$ & $\begin{array}{r}0.0114 \\
\text { Hapto }_{>3}(47 \%) \\
\text { Chloro }_{>3}(42 \%) \\
\text { Dino }_{>3}(11 \%)\end{array}$ & -168.6 & -7.7 & -0.85 & -1.50 & -0.007 \\
\hline
\end{tabular}

pigment determination on fractionated samples is relevant in providing size-related taxonomical information (e.g., Brunet and Lizon, 2003; Brunet et al., 2006, 2007). The approach used in this paper parallels flow cytometry with HPLC pigment measurements on fractionated samples to obtain deeper insights of cell size-related phytoplankton community dynamics. Specifically, we investigated how the physiological state and composition of a natural phytoplankton community, adapted to high light and nutrient paucity (oligotrophic coastal surface system), is modified by sudden increases in nutrient availability.

Induced variations in taxonomic, cell size and functional diversity of phytoplankton communities result in competition or coexistence of multiple species (Hutchinson, 1961; Tilman et al., 1982). Functional changes in phytoplankton cell size and functional groups diversified by peculiar biogeochemical properties (Iglesias-Rodriguez et al., 2002), for instance associated with nitrogen-fixation (Le Quéré et al., 2005; Agawin et al., 2007), diatom/cyanobacterial association (Carpenter et al., 1999), or even mixotrophy ability (Raven, 1997), cause the alternation of successful species whose eco-physiological characteristics will eventually determine the quality (elemental and biochemical composition) and quantity of primary production transferred up to the marine food web (Finkel et al., 2010 and references therein).

Different cell size-related dynamics of change in phytoplankton community structure and composition are found in the studied ecosystem. Picophytoplankton respond to the first input of nutrients, while nano- and microphytoplankton response is mainly relevant soon after the second one. The rapid response of picophytoplankton fits their dominance and ability to out-compete bigger cells (e.g., Chlorophyceae, see below) in extreme environmental conditions (i.e., the nutrient limitation and high light of the studied surface waters), having a higher efficiency in physiological processes (and possibly growth rates), in low-resource habitats, when compared to bigger phytoplankters (Raven, 1998; Raven et al., 2005).

Dust deposition has been demonstrated to affect the community structure of both phytoplankton and bacterioplankton in the central Atlantic Ocean (Marañón et al., 2010), and in the NW Mediterranean Sea (Pulido-Villena et al., 2008; Romero et al., 2011), with an early and predominant response of heterotrophic bacteria shortly after nutrient pulses due to dust additions. Our study shows how the picoplankton (autotrophic and heterotrophic) community is able to quickly respond to sudden new nutrient inputs, with an enhancement of the bacterial respiration soon after the first dust addition, while remaining constant and higher than in CM until the end of the experiment (Pulido-Villena et al., 2013). A dustinduced greater bacterial biomass production, relative to phytoplankton primary production, has been observed in relation with the degree of oligotrophy of the ecosystem (Marañón et al., 2010). However, during our experiment, bacterial abundance is controlled by viruses and, to a lesser extent, by heterotrophic nanoflagellates, especially after the second dust addition (Pulido-Villena et al., 2013).

In the autotrophic picoplankton community, Cyanophyceae and, to a lesser extent Haptophyceae, are the major players responding to nutrient pulses, in agreement with studies reporting the impact of macronutrient deprivation on 
(a) NPQ - DM

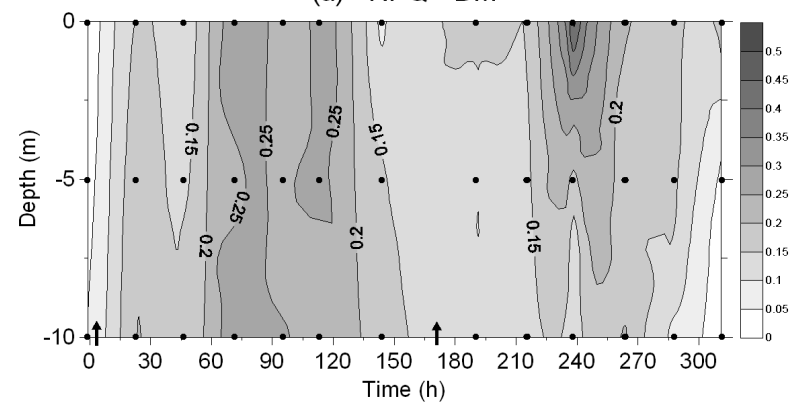

(b) $\mathrm{NPQ}-\mathrm{CM}$

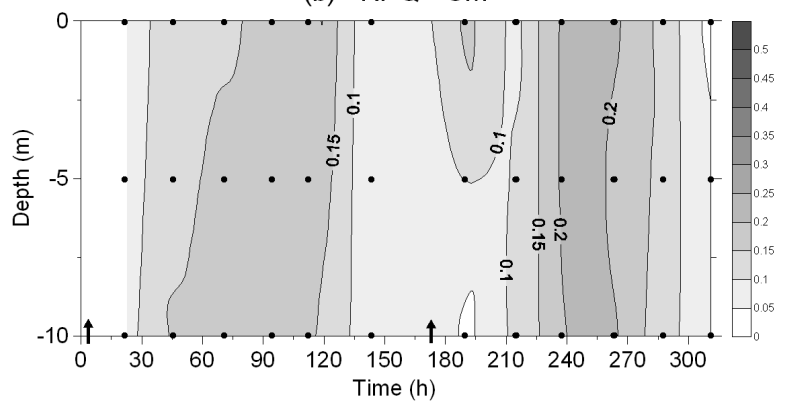

Fig. 7. Evolution of the non-photochemical fluorescence quenching (NPQ) mean values of the phytoplankton community in dust-amended mesocosms (DM; (a) and control mesocosms (CM; (b), over time (hours). The arrows indicate the time at which each dust addition was performed.

Cyanophyceae (e.g., Kana et al., 1992; Collier et al., 1994) and Haptophyceae cultures growth (e.g., Riegman et al., 2000). This feature highlights the opportunistic behaviour of these groups under low-nutrient, low-chlorophyll and high light conditions, driven by allochthonous energy inputs. This first response does not induce any change in the community structure, being only a further increase of the already dominant picophytoplankton biomass, even if it leads to an enhancement of their contribution. In contrast, the larger cell-sized phytoplankton need three days to be able of a biomass increase, which is a quite long lag time that relates to the low biomass of nano- and microphytoplankton at the beginning of the experiment, possibly linked to the unhealthy physiological state of larger cells and competitive disadvantage relative to smaller ones. Nano- and microphytoplankton biomass increase is strongly limited by the low concentration of nutrients present at the sea surface layer, after the picophytoplankton bloom following the first dust addition. In contrast, a biomass increase of large cell-sized Haptophyceae and Chlorophyceae, even if slightly lower than the picophytoplankton biomass increase, relies upon the second pulse of nutrients, contributing to $\sim 50 \%$ of the total biomass.

These results highlight that, during few days, the second dust addition determines relevant modifications in the ecological properties and trophic state of the first ten metres of the water column, possibly causing a switch from oligotrophic to mesotrophic regimes in the system. Unfortunately, our experimental setup did not allowed to further investigate how such changes in the phytoplankton community composition affected the trophic web interactions.

In response to the second dust addition, not only nanoand microphytoplankton biomass increases, but also picophytoplankton biomass, with prevalent contributions of Haptophyceae, Cyanophyceae and Pelagophyceae. This increase in total biomass requires all the available nutrients, more strongly exploiting both nitrate $(-168.65 \mu \mathrm{g}$ $\left.\mathrm{NO}_{3}^{-} \mathrm{L}^{-1} \mathrm{~d}^{-1}\right)$ and phosphate $\left(-7.7 \mu \mathrm{g} \mathrm{PO}_{4}^{3-} \mathrm{L}^{-1} \mathrm{~d}^{-1}\right)$, in comparison to the biomass increase occurring after the first dust addition (Table 2), with the dissolved inorganic phosphorus being also partially depleted by bacterial assimilation (Pulido-Villena et al., 2013). The estimated N/P ratio used for phytoplankton growth is $\sim 22$, i.e., relatively close to the Redfield ratio value.

During the first dust addition, a similar nitrogen $\left(\left[\mathrm{NO}_{3}^{-}\right]\right.$ $\left.+\left[\mathrm{NO}_{2}^{-}\right]\right) /$phosphate $\left(\left[\mathrm{PO}_{4}^{3-}\right]\right)$ ratio characterises both the picophytoplankton (84.3, increase of the second day) and the nano- and microphytoplankton nutrient assimilation (92, increase of the third day). We believe that this result reflects a nitrate and phosphate colimitation of the nano- and microplanktonic community, that in turn caused the long lag time for growth.

A striking finding is the relevant contribution of Chlorophyceae to nano- and microplankton biomass, despite being undetectable before the second dust addition or in control conditions. This result underlines the high nutrient concentration-requirement of this class for growth (in agreement with nutrient availability after the second dust addition), and is consistent with the presence of Chlorophyceae (at least the picophytoplankton size class) in DCM layers of oligotrophic ecosystems (Brunet et al., 2006, 2007). Chlorophyceae occurrence in the DCM has been mainly related to their pigment properties, and notably to the presence of $\mathrm{Chl} b$, which is particularly suited to exploit the dim blue-light environment of such depths (Bidigare and Marra, 1990; Brunet et al., 2006). By comparing this study with previous ones (Brunet et al., 2006, 2007), we can, therefore, assume that both the low light environment and nutrient availability are the main triggers controlling the presence of nano- and microphytoplanktonic Chlorophyceae in the DCM. The presence of the pigment prasinoxanthin together with $\mathrm{Chl} b$ (data not shown) indicates that a portion of the $\mathrm{Chl} b$-containing species is related to the prasinoxanthincontaining class Prasinophyceae, as already reported in the water layer above the depth of $70 \mathrm{~m}$, in the Mediterranean Sea (Brunet et al., 2006). 


\subsection{Effects of the dust additions on the physiological state of the phytoplankton community}

Concomitant to changes in the composition and structure of the phytoplankton community, the physiological state of the community evolves, as shown by the increase of the pigment content per cell in picophytoplankton, a response that was also previously reported in LNLC region surface layers of the Atlantic Ocean (Davey et al., 2008; Moore et al., 2008).

By taking advantage of the absent detection of Prochlorococcus, we combined HPLC-fractionated pigment and flow cytometry data to estimate the zeaxanthin (Zeax) content per Synechococcus cell. Synechococcus Zeax cellular content ranges between 0.3 and 1.5 fg Zeax cell ${ }^{-1}$, being lower than previously reported in literature (Kana et al., 1988; Morel et al., 1993; Moore et al., 1995). It should be noticed that, these studies show pigment content measured in laboratory cultures under nutrient-replete conditions and optimal temperature and light, factors that significantly affect phytoplankton pigment changes. In contrast, our data refer to samples collected in surface waters and during summer, thus, representative of a phytoplankton community undergoing quite extreme regimes of high light and oligotrophy. We show that increasing nutrient concentrations cause a rapid enhancement of the pigment content per cell, reflecting nutrient-dependent processes within photosystems of Synechococcus cells that are experiencing a healthy physiological state. Indeed, nitrogen starvation has been reported to differently affect phycobiliprotein regulation and energy transfer from phycoerythrin to the electron transport chain, in Synechococcus sp. strains originating from oceanic or coastal marine ecosystems (Kana et al., 1992), as well as nutrient deprivation is known to impact Synechococcus sp. PSII activity (Collier et al., 1994).

The chlorophyll (Chl) $a$ content per picophytoplankton cell ranges from 1.5 to $3.4 \mathrm{fg} \mathrm{Chl} a_{<3}$ cell $^{-1}$, also increasing with new nutrient inputs, as cellular physiological responses and/or species succession occur. In comparison with other studies (e.g., Brunet et al., 2006, 2008; Dimier et al., 2009a, b), the Chl $a$ content per picophytoplankton cell is quite low, in agreement with the high contribution of Synechococcus at the beginning of the experiment, while picoeukaryotic biomass of Haptophyceae and Pelagophyceae increases along the experiment evolution. Both the lower $\mathrm{Chl} a$ cellular content of Synechococcus relative to picoeukaryotes, as well as to the high light acclimation of cells inhabiting surface water layers, explain this low Chl $a$ content per picophytoplankton cell. Brunet et al. (2006) have previously estimated values of Chl $a$ content per picoeukaryotic cell (after excluding the Synechococcus contribution) of $\sim 10 \mathrm{fg} \mathrm{Chl} a$ cell $^{-1}$ in the surface water layer of the Mediterranean sea (with a depth between 10 and $25 \mathrm{~m}$ ), while in cultures, values have been reported to vary between 50 and $150 \mathrm{fg} \mathrm{Chl} a$ cell $^{-1}$ (Dimier et al., 2007, 2009a, b; Giovagnetti et al., 2010). In situ studies dealing with photobiological properties of picoeukaryotes revealed a strong capacity of these small cells to modify their Chl $a$ content in relation to the light environment, due to both species succession and physiological acclimation (e.g., Brunet et al., 2006).

Concerning the nano- and microphytoplankton community, we report Chl $a$ cellular content values ranging between 20 and $60 \mathrm{fg} \mathrm{Chl} a$ cell $^{-1}$. As found for the picophytoplankton community, the values of nano- and microphytoplankton $\mathrm{Chl} a$ cellular content are lower than the ones measured in laboratory cultures (Stolte et al., 2000), even under high light stress (LaRoche et al., 1991), possibly underlining the effect that nutrient-replete conditions might have on modifying the cellular pigment content in phytoplankton.

At the photophysiological level, a rapid photoprotective response (i.e., NPQ development) is found soon after the first dust addition and remains quite high during few days, before decreasing during nutrient concentration lowering. The highest value of NPQ developed in response to the second dust addition might be due to the higher contribution of nanoand micro-phytoplanktonic species, that might have a greater capacity to enhance NPQ than smaller ones (as the case of diatoms for instance; Brunet et al., 2011). The overall decrease in Cyanophyceae after the second dust addition might have also contributed to the dynamics of NPQ modulation, in agreement to their lower NPQ capacity relative to eukaryotic species (Brunet et al., 2011 and references therein), also in function of their high light adaptation, as they tend to occupy the surface water layer of oligotrophic areas, as also described in the Mediterranean Sea (Brunet et al., 2006, 2007).

Modifications of the physiological state of the phytoplankton community are furthermore underlined by comparing our results on gross primary production (relative electron transport rate; rel ETR $_{\max }$ ) with the isotopic measurements of net primary production $\left({ }^{13} \mathrm{C} \mathrm{PP}\right.$; data available only at $5 \mathrm{~m}$ depth; Ridame et al., 2013).

Plots of ${ }_{\text {rel }}$ ETR $_{\max }$ and ${ }^{13} \mathrm{C}$ PP highlight a different regulation of the photosynthetic process of the two phytoplankton size classes (Fig. 8). Both measurements are not correlated by pooling together all data of control and dust mesocosms, or only using dataset of dust mesocosms (data not shown). By separating the two dust additions, no significant correlation is found during the first dust addition period (Fig. 8a), whereas relETR $\max$ and ${ }^{13} \mathrm{C}$ PP are significantly correlated during the second dust addition period $\left(R^{2}=0.29, p<0.05\right.$; Fig. 8 b). It should be noticed that gross and net primary production are significantly correlated in control mesocosms $\left(R^{2}=0.30, p<0.01\right.$; Fig. 8c), as expected for a picophytoplankton-predominant community, ecophysiologically adapted to oligotrophy.

When nutrients are added to the system, net primary production increases, and two distinct responses are found, depending on phytoplankton cell size constraints. During the first dust addition, when the community is largely dominated by picophytoplankton, and among them Cyanophyceae, the increase in net primary production is not related to an enhanced ETR, but probably to a more efficient use of the 
(a) First Dust Addition

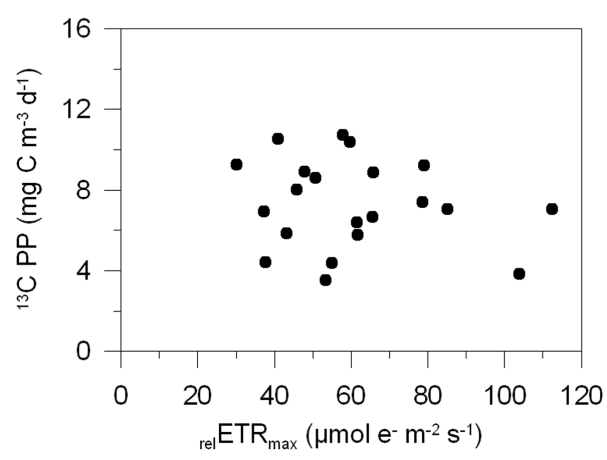

(b) Second Dust Addition

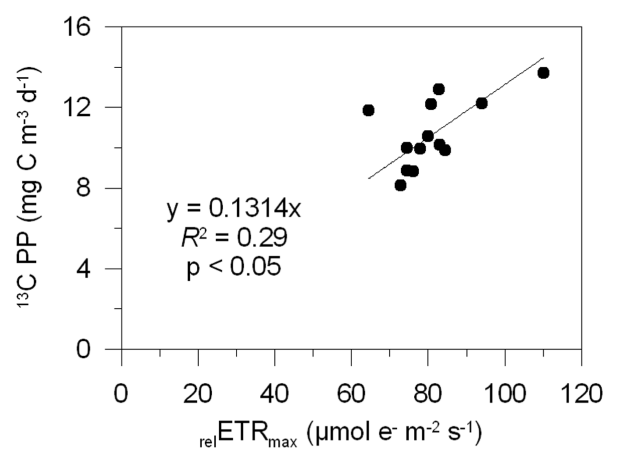

(c) Control Mesocosms

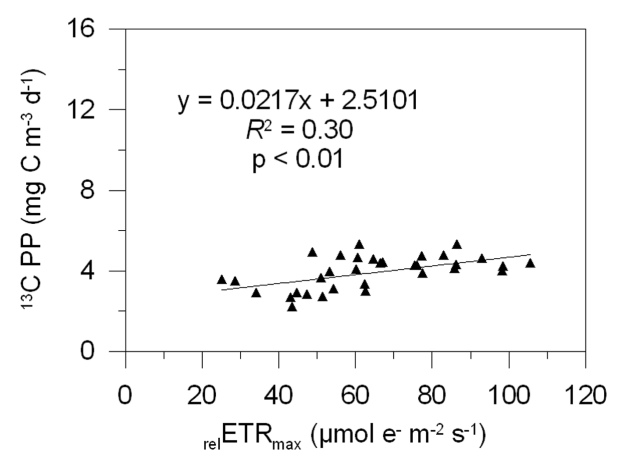

Fig. 8. Relationship between ${ }^{13} \mathrm{C}$ isotopic measurement of net primary production $\left({ }^{13} \mathrm{C} \mathrm{PP} ; \mathrm{mg} \mathrm{C} \mathrm{m}^{-3} \mathrm{~d}^{-1}\right)$ and relative electron transport rate $\left(\mathrm{rel}_{\mathrm{eTR}} \mathrm{max} ; \mu \mathrm{mol} \mathrm{e}^{-} \mathrm{m}^{-2} \mathrm{~s}^{-1}\right)$, during the first (a) and the second dust addition (b), and during the entire experiment within the control mesocosms (c). The plotted data represent samples collected at $-5 \mathrm{~m}$ depth.

products synthesized during the photosynthetic reactions (e.g., by decreasing the photorespiration rate). In this case, we can hypothesise that the greater uptake of nutrients, mainly by Haptophyceae and Cyanophyceae, is not due to an increase in the flux of electrons within PSII, but probably to a more efficient regulative strategy to produce biomass.
We can, thus, hypothesise that new nutrient inputs would act primarily on carbon reduction reactions (at the level of the Calvin Cycle), rather than on early photons harvesting and excitation energy transfer within PSII.

The stronger increase in nano- and microphytoplankton biomass after the second than the first dust addition seems instead to explain the significant correlation between ${ }_{\text {rel }}$ ETR $_{\max }$ and ${ }^{13} \mathrm{C}$ PP found in the dataset concerning the second dust addition. This result possibly suggests that, in a community in which the abundance of large-sized cells becomes relevant, net and gross primary production increase because of an enhanced PSII ETR, indicating the direct effect of nutrient limitation on cells capacity of light capture and/or PSII excitation energy transfer.

We may, therefore, infer that the regulation of photobiological processes is differently influenced by nutrient availability in both phytoplankton size classes, in agreement with previous studies (Mei et al., 2009; Chen and Liu, 2010), recalling the metabolic theory of ecology (Brown et al., 2004). Insofar, regulative physiological and biochemical mechanisms, activated during nutrient limitation or repletion regimes, would operate at two different levels of the photosynthetic process, in relation to phytoplankton cell-size dependent energy-requirements of biomass synthesis.

Our results demonstrate that dust additions can relevantly impact both the nutrient availability and phytoplankton community of this LNLC surface waters. Picophytoplankton are the first group among the autotrophic organisms that responds to such dust additions, in terms of both ecophysiological state of cells and community composition. On the contrary, bigger-sized cells need a further nutrient supply to adjust their physiology and compete for resource acquisition and biomass increase. We can hypothesize that multiple dust additions, occurring on a large area of the Mediterranean Sea (Bergametti et al., 1989; Guieu et al., 2010a) might, thus, significantly affect the functioning and productivity of Mediterranean LNLC ecosystems.

Acknowledgements. This work was funded by the ANR-DUNE under the contract "ANR-07-BLAN-30 0126-01". V. Giovagnetti's $\mathrm{PhD}$ was financially supported by the Stazione Zoologica A. Dohrn. J. M. Dominici and collaborators of the "Réserve naturelle de Scandola, Parc naturel régional de Corse" are gratefully acknowledged for their help and cooperation in performing the experiments and implementing the field work conducted in the bay of Elbo. P. Catala is acknowledged for having performed cytometry analysis. The authors would like to thank all the participants of the DUNE-2 project, which were involved in developing the experimental design and performing the experiments. Comments by two anonymous reviewers have been very helpful to improve the quality of this manuscript.

Edited by: E. Marañón 


\section{References}

Agawin, N. S. R., Rabouille, S., Veldhuis, M. J. W., Servatius, L., Hol, S., Overzee, H. M. J., and Huisman, J.: Competition and facilitation between unicellular nitrogen-fixing cyanobacteria and non-nitrogen-fixing phytoplankton species, Limnol. Oceanogr., 52, 2233-2248, 2007.

Agogué, H., Casamayor, E. O., Joux, F., Obernosterer, I., Dupuy, C., Lantoine, F., Catala, P., Weinbauer, M. G., Rheinthaler, T., Herndl, G. J., and Lebaron, P.: Comparison of samplers for the biological characterization of the sea surface microlayer, Limnol. Oceanogr. Methods, 2, 213-225, 2004.

Bartoli, G., Migon, C., and Losno, R.: Atmospheric input of dissolved inorganic phosphorus and silicon to the coastal northwestern Mediterranean Sea: ?uxes, variability and possible impact on phytoplankton dynamics, Deep-Sea Res. Pt. I, 52, 2005-2016, 2005.

Behrenfeld, M. J., Worthington, K., Sherrell, R. M., Chavez, F. P., Strutton, P., McPhaden, M., and Shea, D. M.: Controls on tropical Pacific Ocean productivity revealed through nutrient stress diagnostics, Nature, 442, 1025-1028, 2006.

Behrenfeld, M. J., Westberry, T. K., Boss, E. S., O’Malley, R. T., Siegel, D. A., Wiggert, J. D., Franz, B. A., McClain, C. R., Feldman, G. C., Doney, S. C., Moore, J. K., Dall'Olmo, G., Milligan, A. J., Lima, I., and Mahowald, N.: Satellite-detected fluorescence reveals global physiology of ocean phytoplankton, Biogeosciences, 6, 779-794, doi:10.5194/bg-6-779-2009, 2009.

Bergametti, G., Dutot, A. L., Buat-Menard, P., Losno, R., and Remoudaki, E.: Seasonal variability of the elemental composition of atmospheric aerosol particles over the northwestern Mediterranean, Tellus B, 41, 353-361, 1989.

Bergametti, G., E. Remoudaki, R. Losno, E. Steiner, and Chatenet, B.: Source, transport and deposition of atmospheric phosphorus over the northwestern Mediterranean, J. Atmos. Chem., 14, 501513, doi:10.1007/BF00115254, 1992.

Bidigare, R. R. and Marra, J.: Evidence for phytoplankton succession and chromatic in the Sargasso sea during spring 1985, Mar. Ecol. Prog. Ser., 60, 113-122, 1990.

Blain, S., Guieu, C., Claustre, H., Leblanc, K., Moutin, T., Quéguiner, B., Ras, J., and Sarthou, G.: Availability of iron and major nutrients for phytoplankton in the northeast Atlantic Ocean, Limnol. Oceanogr., 49, 2095-2104, 2004.

Blain, S., Bonnet, S., and Guieu, C.: Dissolved iron distribution in the tropical and sub tropical South Eastern Pacific, Biogeosciences, 5, 269-280, doi:10.5194/bg-5-269-2008, 2008.

Bonnet, S. and Guieu, C.: Atmospheric forcing on the annual iron cycle in the western Mediterranean Sea: A 1-year survey, J. Geophys. Res., 111, C09010, doi:10.1029/2005JC003213, 2006.

Bonnet, S., Guieu, C., Chiaverini, J., Ras, J., and Stock, A.: Effect of atmospheric nutrients on the autotrophic communities in a low nutrient, low chlorophyll system, Limnol. Oceanogr., 50, 18101819, 2005.

Boyd, P. W., Jickells, T. D., Law, C. S., Blain, S., Boyle, E. A., Buesseler, K. O., Coale, K. H., Cullen, J. J., de Baar, H. J. W., Follows, M., Harvey, M., Lancelot, C., Levasseur, M., Owens, N. P. J., Pollard, R., Rivkin, R. B., Sarmiento, J., Schoemann, V., Smetacek, V., Takeda, S., Tsuda, A., Turner, S., and Watson, A. J.: Mesoscale iron enrichment experiments 1993-2005: Synthesis and future directions, Science, 315, 612-617, 2007.
Brown, J. H., Gillooly, J. F., Allen, A. P., Savage, V. M., and West, G. B.: Toward a metabolic theory of ecology, Ecology, 85, 17711789, 2004.

Brunet, C. and Lizon, F.: Tidal and diel periodicities of size fractionated phytoplankton pigment signatures at an offshore station in the South-Eastern English Channel, Estuar. Coast. S., 56, 835845, 2003.

Brunet, C., Casotti, R., Vantrepotte, V., Corato, F., and Conversano, F.: Picophytoplankton diversity and photophysiology in the Strait of Sicily (Mediterranean Sea) in summer. I. Mesoscale variations, Aquat. Microb. Ecol., 44, 127-141, 2006.

Brunet, C., Casotti, R., Vantrepotte, V., and Conversano, F.: Vertical variability and diel dynamics of picophytoplankton in the Strait of Sicily (Mediterranean Sea) in summer, Mar. Ecol. Prog. Ser., 346, 15-26, 2007.

Brunet, C., Casotti, R., and Vantrepotte, V.: Phytoplankton diel and vertical variability in photobiological responses at a coastal station in the Mediterranean Sea, J. Plankton Res., 30, 645-654, 2008.

Brunet, C., Johnsen, G., Lavaud, J., and Roy, S.: Selected pigment applications in oceanography, Pigments and photoacclimation processes, in Roy, S., Johnsen, G., Llewellyn, C., and Skarstad, E. (eds), Phytoplankton Pigments in Oceanography: Guidelines to Modern Methods, Series: Oceanographic Methodologies, Vol. 2. SCOR-UNESCO, Publishing, Cambridge University Press, Cambridge, 2011.

Carpenter, E. J., Montoya, J. P., Burns, J., Mulholland, M. R., Subramaniam, A., and Capone, D. G.: Extensive bloom of a $\mathrm{N}_{2}$-fixing diatom/cyanobacterial association in the tropical Atlantic Ocean, Mar. Ecol. Prog. Ser., 185, 273-83, 1999.

Casotti, R., Landolfi, A., Brunet, C., D’Ortenzio, F., Mangoni, O., Boldrin, A., Ribera d'Alcalà, M., and Denis, M.: Composition and dynamics of the phytoplankton of the Ionan Sea (Eastern Mediterranean), J. Geophys. Res., 108, 8116, doi:10.1029/2002JC001541, 2003.

Chen, B. Z. and Liu, H. B.: Relationships between phytoplankton growth and cell size in surface oceans: Interactive effects of temperature, nutrients, and grazing, Limnol. Oceanogr., 55, 965972, 2010.

Chisholm, S. W., Olson, R. J., Zettler, E. R., Goericke, R., Waterbury, J. B., and Welschmeyer, N. A.: A novel free-living prochlorophyte abundant in the oceaniceuphotic zone, Nature, 334, 340-343, 1988.

Chisholm, S. W., Frankel, S.L., Goericke, R., Olson, R. J., Palenik, B., Waterbury, J. B.,West-Johnsrud, L., and Zettler, E. R.: Prochlorococcus marinus nav. gen. nov.sp. Anoxytrophic marine prokaryote containing divinyl chlorophyll $a$ and $b$, Archiv fur Mikrobiol., 157, 297-300, 1992.

Collier, J. L., Herbert, S. K., Fork, D. C., and Grossman, A. R.: Changes in the cyanobacterial photosynthetic apparatus during acclimation to macronutrient deprivation, Photosynth. Res., 42, 173-183, 1994.

Cullen, J. J.: The deep chlorophyll maximum: comparing vertical profiles of chlorophyll $a$, Can. J. Fish. Aquat. Sci., 39, 791-803, 1982.

Davey, M., Tarran, G. A., Mills, M. M., Ridame, C., Geider, R. J., and LaRoche, J.: Nutrient limitation of picophytoplankton photosynthesis and growth in the tropical North Atlantic, Limnol. Oceanogr., 53, 1722-1733, 2008. 
Díez, B., Pedrós-Alió, C., and Massana, R.: Study of genetic diversity of eukaryotic picoplankton in different oceanic regions by small-subunit rRNA gene cloning and sequencing, Appl. Environ. Microbiol., 67, 2932-2941, 2001.

Dimier, C., Corato, F., Saviello, G., and Brunet, C.: Photophysiological properties of the marine picoeukaryote Picochlorum RCC237 (Trebouxiophyceae,Chlorophyta), J. Phycol., 43, 275283, 2007.

Dimier, C., Brunet, C., Geider, J. R., and Raven, J. A.: Growth and photoregulation dynamics of the picoeukaryote Pelagomonas calceolata in fluctuating light, Limnol. Oceanogr., 54, 823-836, 2009a.

Dimier, C., Saviello, G., Tramontano, F., and Brunet, C.: Comparative ecophysiology of the xanthophyll cycle in six marine phytoplanktonic species, Protist, 160, 397-411, $2009 \mathrm{~b}$.

Duce, R. A., Liss, P. S., Merrill, J. T., Atlas, E. L., Buat-Menard, P., Hicks, B. B., Miller, J. M., Prospero, J. M., Arimoto, R., Church, T. M., Ellis, W., Galloway, J. N., Hansen, L., Jickells, T. D., Knap, A. H., Reinhardt, K. H., Schneider, B., Soudine, A., Tokos, J. J., Tsunogai, S., Wollast, R., and, Zhou, M.: The atmospheric input of trace species to the world ocean, Global Biogeochem. Cy., 5, 193-259, 1991.

Eilers, P. H. C. and Peeters, J. C. H.: A model for the relationship between light intensity and the rate of photosynthesis in phytoplankton, Ecol. Model., 42, 199-215, 1988.

Eppley, R. W. and Peterson, B. J.: Particulate organic matter flux and planktonic new production in the deep ocean, Nature, 282, 677-680, 1979.

Finkel, Z. V., Beardall, J., Flynn, K. J., Quigg, A., Rees, T. A., and Raven, J. A.: Phytoplankton in a changing world: cell size and elemental stoichiometry, J. Plankton Res., 32, 119-137, 2010.

Giovagnetti, V., Cataldo, M.L., Conversano, F., and Brunet, C.: Functional relation between growth, photosynthetic rate and regulation in the coastal picoeukaryote Phaeomonas sp. RCC 503 (Pinguiophyceae, Stramenopiles), J. Plankton Res., 32, 1501$1511,2010$.

Giovagnetti, V., Cataldo, M.L., Conversano, F., and Brunet, C.: Growth and photophysiological responses of two picoplanktonic Minutocellus species, strains RCC967 and RCC703 (Bacillariophyceae), Eur. J. Phycol., 47, 408-420, 2012.

Gould, R. W.: The deep chlorophyll maximum in the world ocean: a review, Biologist, 66, 4-13, 1987.

Guerzoni, S., Chester, R., Dulac, F., Herut, B., Loÿe-Pilot, M. D., Measures, C., Migon, C., Molinaroli, E., Moulin, C., Rossini,P., Saydam, C., Soudine, A., and Ziveri, P.: The role of atmospheric deposition in the biogeochemistry of the Mediterranean Sea, Prog. Oceanogr., 44, 147-190, 1999.

Guieu, C., Loÿe-Pilot, M.-D., Ridame, C., and Thomas, C.: Chemical characterization of the Saharan dust end-member: Some biogeochemical implications for the western Mediterranean Sea, J. Geophys. Res.,107, D15, doi:10.1029/2001JD000582, 2002.

Guieu, C., Loÿe-Pilot, M.-D., Benyaya, L., and Dufour, A.: Spatial variability of atmospheric fluxes of metals ( $\mathrm{Al}, \mathrm{Fe}, \mathrm{Cd}, \mathrm{Zn}$ and $\mathrm{Pb}$ ) and phosphorus over the whole Mediterranean from a one year monitoring experiment: biogeochemical implications, Mar. Chem., 120, 164-178, 2010a.

Guieu, C., Dulac, F., Desboeufs, K., Wagener, T., Pulido-Villena, E., Grisoni, J.-M., Louis, F., Ridame, C., Blain, S., Brunet, C., Bon Nguyen, E., Tran, S., Labiadh, M., and Dominici, J.-M.:
Large clean mesocosms and simulated dust deposition: a new methodology to investigate responses of marine oligotrophic ecosystems to atmospheric inputs, Biogeosciences, 7, 27652784, doi:10.5194/bg-7-2765-2010, 2010b.

Guieu, C., Dulac, F., Ridame, C., and Pondaven, P.: Introduction to the DUNE project a DUst experiment in a low Nutrient, low chlorophyll Ecosystem, Biogeosciences, in preparation, 2013.

Hofstraat, J. W., Peeters, J. C. H., Snel, J. F. H., and Geel, C.: Simple determination of photosynthetic efficiency and photoinhibition of Dunaliella tertiolecta by saturating pulse fluorescence measurements, Mar. Ecol. Prog. Ser., 103, 187-196, 1994.

Hutchinson, G. E.: The paradox of the plankton, Am. Nat., 95, 137$145,1961$.

Iglesias-Rodriguez, D. M., Brown, C. W., Doney, S. C., Kleypas, J. A., Kolber, D., Kolber, Z., Hayes, P. K., and Falkowski, P. G.: Representing key phytoplankton functional groups in ocean carbon cycle models: Coccolithophorids, Global Biogeochem. Cy., 16, 1100, doi:10.1029/2001GB001454, 2002.

Jickells, T. D., An, Z. S., Andersen, K. K., Baker, A. R., Bergametti, G., Brooks, N., Cao, J. J., Boyd, P. W., Duce, R. A., Hunter, K. A., Kawahata, H., Kubilay, N., LaRoche, J., Liss, P. S., Mahowald, N., Prospero, J. M., Ridgwell, A. J., Tegen, I., and Torres, R.: Global iron connections between desert dust, ocean biogeochemistry, and climate, Science, 308, 67-71, 2005.

Jordi, A., Basterretxea, G., Tovar-Sánchez, A., Alastuey, A., and Querol, X.: Copper aerosols inhibit phytoplankton growth in the Mediterranean Sea, Proc. Natl. Acad. Sci. USA, 109, 2124621249, doi:10.1073/pnas.1207567110, 2012.

Kana, T. M., Glibert, P. M., Goericke, R., and Welschmeyer, N. A.: Zeaxanthin and $\beta$ carotene in Synechococcus WH 7803 respond differently to irradiance, Limnol. Oceanogr., 33, 1623$1627,1988$.

Kana, T. M., Feiwel, N.L., and Flynn, L. C.: Nitrogen starvation in marine Synechococcus strains: clonal differences in phycobiliprotein breakdown and energy coupling, Mar. Ecol. Prog. Ser., 88, 75-82, 1992.

LaRoche, J., Mortain-Bertrand, A., and Falkowski, P. G.: Light intensity-induced changes in $c a b$ mRNA and light harvesting complex II apoprotein levels in the unicellular chlorophyte Dunaliella tertiolecta, Plant Physiol., 97, 147-153, 1991.

Law, C. S., Woodward, E. M. S., Ellwood, M. J., Marriner, A., Bury, S. J., and Safi, K. A.: Response of surface nutrient inventories and nitrogen fixation to a tropical cyclone in the southwest Pacific, Limnol. Oceanogr., 56, 1372-1385, 2011.

Le Gall, F., Rigaut-Jalabert, F., Marie, D., Garczarek, L., Viprey, M., Gobet, A., and Vaulot, D.: Picoplankton diversity in the SouthEast Pacific Ocean from cultures, Biogeosciences, 5, 203-214, doi:10.5194/bg-5-203-2008, 2008.

Le Quéré, C., Harrison, S. P., Prentice, I. C., Buitenhuis, E. T., Aumont, O., Bopp, L., Claustre, H., Da Cunha, L. C., Geider, R. J., Giraud, X., Klaas, C., Kohfeld, K. E., Legendre, L., Manizza, M., Platt, T., Rivkin, R. B., Sathyendranath, S., Uitz, J., Watson, A. J., and Wolf-Gladrow, D.: Ecosystem dynamics based on plankton functional types for global ocean biogeochemistry models, Glob. Change Biol., 11, 2016-2040, 2005.

Magazzù, G. and Decembri, F.: Primary production, biomass and abundance of phototrophic picoplankton in the Mediterranean Sea: a review, Aquat. Microb. Ecol., 9, 97-104, 1995. 
Mahowald, N. M., Baker, A. R., Bergametti, G., Brooks, N., Duce, R. A., Jickells, T. D., Kubilay, N., Prospero, J. M., and Tegen, I.: Atmospheric global dust cycle and iron inputs to the ocean, Glob. Biogeochem. Cy., 19, GB4025, doi:10.1029/2004GB002402, 2005.

Marañón, E.: Phytoplankton growth rates in the Atlantic subtropical gyres, Limnol. Oceanogr., 50, 299-310, 2005.

Marañón, E., Fernández, A., Mouriño-Carballido, B., MartínezGarcía, S., Teira, E., Cermeño, P., Chouciño, P., Huete-Ortega, M., Fernández, E., Calvo-Díaz, A., Morán, X. A. G., Bode, A., Moreno-Ostos, E., Varela, M. M., Patey, M. D., and Achterberg, E. P.: Degree of oligotrophy controls the response of microbial plankton to Saharan dust, Limnol. Oceanogr., 55, 2339-2352, 2010.

Marie, D., Simon, N., Guillou, L., Partensky, F., and Vaulot, D.: Flow cytometry analysis of marine picoplankton, In De Maggio (ed.), Living color: protocols in flow cytometry and cell sorting, Springer Verlag, Berlin, 421-454, 2000.

Marinov, I., Doney, S. C., and Lima, I. D.: Response of ocean phytoplankton community structure to climate change over the $21 \mathrm{st}$ century: partitioning the effects of nutrients, temperature and light, Biogeosciences, 7, 3941-3959, doi:10.5194/bg-7-39412010, 2010.

Mei, Z.-P., Finkel, Z. V., and Irwin, A.: Light and nutrient availability affect the size-scaling of growth in phytoplankton, J. Theor. Biol., 259, 582-588, 2009.

Mills, M. M., Ridame, C., Davey, M., LaRoche, J., and Geider, R. J.: Iron and phosphorus co-limit nitrogen fixation in the eastern tropical North Atlantic, Nature, 429, 292-294, 2004.

Moon-van der Staay, S. Y., De Wachter, R., and Vaulot, D.: Oceanic $18 \mathrm{~S}$ rDNA sequences from picoplankton reveal unsuspected eukaryotic diversity, Nature, 409, 607-610, 2001.

Moore, L. R., Goericke, R., and Chisholm, S. W.: Comparative physiology of Synechococcus and Prochlorococcus: influence of light and temperature on growth, pigments, fluorescence and absorptive properties, Mar. Ecol. Prog. Ser., 116, 259-275, 1995.

Moore, C. M., Mills, M. M., Langlois, R., Milne, A., Achterger, E. P., LaRoche, J., and Geider, R. J.: Relative influence of nitrogen and phosphorus availability on phytoplankton physiology and productivity in the oligotrophic sub-tropical North Atlantic Ocean, Limnol. Oceanogr., 53, 291-305, 2008.

Morel, A., Ahn, Y. H., Partensky, F., Vaulot, D., and Claustre, H.: Prochlorococcus and Synechococcus: a comparative study of their optical properties in relation to their size and pigmentation, J. Mar. Res., 51, 617-649, 1993.

Not, F., Simon, N., Biegala, I. C., and Vaulot, D.: Application of fluorescent in situ hybridization coupled with tyramide signal amplification (FISH-TSA) to assess eukaryotic picoplankton composition, Aquat. Microb. Ecol., 28, 157-166, 2002.

Not, F., Massana, R., Latasa, M., Marie, D., Colson, C., Eikrem, W., Pedrós-Alió, C., Vaulot, D., and Simon, N.: Alate summer community composition and abundance of photosynthetic picoeukaryotes in Norwegian and Barents Sea, Limnol. Oceanogr., 50, 1677-1686, 2005.

Not, F., Zapata, M., Pazos, Y., Campana, E., Doval, M., and Rodriguez, F.: Size-fractionated phytoplankton diversity in the NW Iberian cost: a combination of microscopic, pigment and molecular analyses, Aquat. Microb. Ecol., 40, 255-265, 2007.
Paerl, H. W., Willey, J. D., Go, M., Peierls, B.L., Pinckney, J. L., and Fogel, M.L.: Rainfall stimulation of primary productionin western Atlantic Ocean waters: Roles of different nitrogen sources and co-limiting nutrients, Mar. Ecol. Prog.Ser., 176, 205-214, 1999.

Partensky, F., Blanchot, J., and Vaulot, D.: Differential distribution and ecology of Prochlorococcus and Synechococcus in oceanic waters: a review, Bull. Inst. Oceanogr. Monaco Numero Spec., 19, 431-449, 1999.

Paytan, A., Mackey, K. R. M., Chen, Y., Lima, I. D., Doney, S. C., Mahowald, N., Labiosa, R., and Post, A. F.: Toxicity of atmospheric aerosols on marine phytoplankton, Proc. Natl. Acad. Sci. USA, 106, 4601-4605, 2009.

Pérez, V., Fernández, E., Marañón, E., Morán, X. A. G., and Zubkov, M. V.: Vertical distribution of phytoplankton biomass, production and growth in the Atlantic subtropical gyres, DeepSea Res. Pt. I, 53, 1616-1634, 2006.

Pulido-Villena, E., Wagener, T., and Guieu, C.: Bacterial responseto dust pulses in the western Mediterranean: Implications for carbon cycling in the oligotrophic ocean, Global Biogeochem. Cy., 22, GB1020, doi:10.1029/2007GB003091, 2008.

Pulido-Villena, E., Baudoux, A.-C., Obernosterer, I., Caparros, J., Catala, P., Georges, C., Harmand, J., Landa, M., and Guieu, C.: Enhanced carbon remineralization by the microbial food web after a dust event in a Low-Nutrient Low-Chlorophyll ecosystem: results from a mesocosm experiment in the Mediterranean Sea, Biogeosciences, in preparation, 2013.

Raven, J. A.: Phagotrophy in autotrophs, Limnol. Oceanogr.,42, 198-205, 1997.

Raven, J. A.: The twelfth Tansley lecture. Small is beautiful: the picophytoplankton, Funct. Ecol., 12, 503-513, 1998.

Raven, J. A., Finkel, Z. V., and Irwin, A. J.: Picophytoplankton: bottom-up and top-down controls on ecology and evolution, Vie Milieu, 55, 209-215, 2005.

Ridame, C. and Guieu, C.: Saharan input of phosphate to the oligotrophic water of the open western Mediterranean Sea, Limnol. Oceanogr., 47, 856-869, 2002.

Ridame, C., Dekaezemacker, J., Guieu, C., Bonnet, S., and L'Helguen, S.: Phytoplanktonic responses to contrasted Saharan dust events: results from dust fertilizations in large mesocosms, Biogeosciences, in preparation, 2013.

Riegman, R., Stolte, W., Noordeloos, A. A. M., and Slezak, D.: Nutrient uptake and alkaline phosphatase (ec 3:1:3:1) activity of Emiliania huxleyi (Prymnesiophyceae) during growth under $\mathrm{N}$ and P limitation in continuous cultures, J. Phycol., 36, 87-96, 2000.

Rodriguez, F., Garrido, J.L., Crespo, B. G., Arbones, B., and Figueiras, F. G.: Size-fractionated phytoplankton pigment groups in the NW Iberian upwelling system: impact of the Iberian Poleward current, Mar. Ecol. Prog. Ser., 323, 59-73, 2006.

Romero, E., Peters, F., Marrasé, C., Guadayol, O., Gasol, J. M., and Weinbauer, M. G.: Coastal Mediterranean plankton stimulation dynamics through a dust storm event: An experimental simulation, Estuar. Coast. Shelf S., 93, 27-39, 2011.

Schreiber, U., Bilger, W., and Neubauer, C.: Chlorophyll fluorescence as a non-intrusive indicator for rapid assessment of in vivo photosynthesis, Ecol. Studies, 100, 49-70, 1994.

Six, C., Finkel, Z. V., Rodriguez, F., Marie, D., Partensky, F., and Campbell, D. A.: Contrasting photoacclimation costs in eco- 
types of the marine eukaryote picoplankter Ostreococcus, Limnol. Oceanogr., 53, 255-265, 2008.

Six, C., Sherrard, R., Lionard, M., Roy, S., and Campbell, D. A.: Photosystem II and pigment dynamics among ecotypes of the green alga Ostreococcus, Plant Physiol., 151, 379-390, 2009.

Stolte, W., Kraay, G. W., Noordeloos, A. A. M., and Riegman, R.: Genetic and physiological variation in pigment composition of Emiliania huxleyi (Prymnesiophyceae) and the potential use of its pigment ratios as a quantitative physiological marker, J. Phycol., 36, 529-539, 2000.

Strzepek, R. F., and Harrison P. J.: Photosynthetic architecture differs in coastal and oceanic diatoms, Nature, 431, 689-692, 2004.

Ternon, E., Guieu, C., Loÿe-Pilot, M.-D., Leblond, N., Bosc, E., Gasser, B., Miquel, J.-C., and Martín, J.: The impact of Saharan dust on the particulate export in the water column of the North Western Mediterranean Sea, Biogeosciences, 7, 809-826, doi:10.5194/bg-7-809-2010, 2010.

Tilman, D., Kilham, S. S., and Kilham, P.: Phytoplankton community ecology: The role of limiting nutrients, Annu. Rev. Ecol. Syst., 13, 349-72, 1982.

Vaulot, D., Eikrem, W., Viprey, M., and Moreau, H.: The diversity of small eukaryotic phytoplankton $(\leq 3 \mu \mathrm{m})$ in marine ecosystems, FEMS Microbiol. Rev., 32, 795-820, 2008.
Veldhuis, M. J. W. and Kraay, G. W.: Vertical distribution and pigment composition of picoplanktonic prochlorophyte in the subtropical North Atlantic: a combined study of HPLC analysis of pigments and flow cytometry, Mar. Ecol. Prog. Ser., 68, 121-127, 1990.

Wagener, T., Guieu, C., and Leblond, N.: Effects of dust deposition on iron cycle in the surface Mediterranean Sea: results from a mesocosm seeding experiment, Biogeosciences, 7, 3769-3781, doi:10.5194/bg-7-3769-2010, 2010.

Waterbury, J. B., Watson, S. W., Guillard, R. R., and Brand, L. E.: Widespread occurrence of a unicellular marine plankton cyanobacteria, Nature, 277, 293-294, 1979.

Wedepohl, K.: The composition of the continental crust, Geochim. Cosmochim. Acta, 59, 1217-1232, 1995.

Worden, A. Z. and Not, F.: Ecology and diversity of picoeukaryotes, in: Microbial Ecology of the Oceans, 2 Edn., edited by: Kirchman, D. L., Wiley, Hoboken, NJ, 159-205, 2008.

Wuttig, K., Wagener, T., Bressac, M., Dammshäuser, A., Streu, P., Guieu, C., and Croot, P. L.: Impacts of dust deposition on dissolved trace metal concentrations ( $\mathrm{Mn}, \mathrm{Al}$ and $\mathrm{Fe}$ ) during a mesocosm experiment, Biogeosciences Discuss., 9, 1385713897, doi:10.5194/bgd-9-13857-2012, 2012. 